\title{
Cumhurbaşkanlığı Hükûmet Sisteminde Bütçe Hakkı ve Kanunu
}

\author{
Power of Purse and Budget Act under the Presidential Government \\ System
}

Ferhat Akbey ${ }^{1}$

RESEARCH

ARTICLE

\begin{tabular}{l} 
ARTICLE INFO \\
\hline Submitted : 17.01 .2020 \\
Revised : 13.03 .2020 \\
Accepted : 30.03 .2020 \\
Available : 24.07.2020 \\
\hline iThenticate similarity \\
score: $9 \%$ \\
\hline JEL classification: \\
H60, H61, H69 \\
\hline Keywords: \\
Presidential \\
Government System, \\
Power of Purse, Budget \\
Act
\end{tabular}

Cite this article as: Akbey, F. (2020). "Cumhurbaşkanlığı Hükûmet Sisteminde Bütçe Hakkı ve Kanunu", International Journal of Public Finance, 5(1), 1-26.

\begin{abstract}
A B S T R A C T
Turkey has switched from Parliamentary Government System to Presidential Government System virtually with the 10 August 2014 presidential elections, legally and partially with the 16 April 2017 referendum, and officially with the 24 June 2018 presidential elections. Hereafter, in this new system, Central Government Budget Bill and Final Accounts Bill can only be proposed by the President to the Parliament; however interestingly, then these bills are finally approved by the same President after they pass the parliamentary processes. Because the fact that there are nevermore obstacles on the President to be an official political party leader, the system has some potentials to exhibit hazardous effects on the Turkish Grand National Assembly's power of the purse, on the sovereignty of the nation, and also on the President's fiscal policy discretions. Expansion of the right of the executive branch to make transfers between sections of the budget, and even the abolishment of Constitutional ground for the parliament's jurisdiction to make such transfers exhibit a serious risk on the power of the purse. Furthermore, the appointment of the Attorney General of the Audit Court (that also audits the Presidency on behalf of the Parliament) by the President and the limitation of his/her tenure by the President's term of office, bring a "politization" risk for the audit of the budget. Another risk is that the President has nothing to do against the authority of the Budget Commission to make almost infinite changes on the Budget of the President, which is the main apparatus to apply his/her fiscal policy; because $s($ he) has no right to veto these changes.
\end{abstract}

\footnotetext{
1 Assoc. Prof. Dr., Erciyes University, Department of Public Finance, Turkey, ORCID: 0000-0002-08863172, ferhatakbey@erciyes.edu.tr, ferhatakbey@gmail.com
} 
Akbey, F. (2020). "Cumhurbaşkanlığı Hükûmet Sisteminde Bütçe Hakkı ve Kanunu”, International Journal of Public Finance, 5(1), 1-26.

In this study, in the context of representative democracy and within the framework of Parliament's power of purse, these potential problems of the new government system are evaluated and resolutions are offered.

\begin{tabular}{l} 
MAKALE Bílgisi \\
\hline Gönderme: 17.01 .2020 \\
Düzeltme : 13.03 .2020 \\
Kabul $\quad: 30.03 .2020$ \\
Yayın : 24.07.2020 \\
\hline iThenticate benzerlik \\
oranı: \%9 \\
\hline
\end{tabular}

JEL Kodu:

H60, H61, H69

Anahtar Kelimeler:

Cumhurbaşkanlığı

Hükûmet Sistemi,

Bütçe Hakkı, Bütçe

Kanunu

\begin{abstract}
Ö Z E T
Türkiye, 24 Haziran 2018 Cumhurbaşkanlığı seçimi ile fiilen ve resmen Cumhurbaşkanlığı Hükûmet Sistemine geçmiştir. Yeni sistemde Merkezi Yönetim Bütçe Kanunu ve Kesinhesap Kanunu ancak Cumhurbaşkanınca Parlamentoya "teklif" edilebilmekte; lâkin ilginç biçimde yine Cumhurbaşkanının nihai onayına gitmektedir. Bu sistemde Cumhurbaşkanının siyasi parti genel başkanı olmasının önünde bir engel de bulunmadığından; sistem, Türkiye Büyük Millet Meclisi'nin bütçe hakkına ve ayrıca Cumhurbaşkanının da maliye politikası hakkına, olumsuz etkide bulunabilme potansiyeli taşımaktadır. Bütçede hükûmetin bölümler arası aktarma yetkisinin genişletilmesi, hatta bu süreçte Meclis'in sahip olduğu yetkinin Anayasal dayanağının ortadan kaldırılması ciddi bir risk teşkil etmektedir. Yine Meclis adına Cumhurbaşkanlığını denetleyen Sayıştay Başsavcısının Cumhurbaşkanınca atanması ve görev süresinin Cumhurbaşkanının süresi ile aynı olması, bütçe denetiminin "siyasallaşma" riskini beraberinde getirmektedir.

Bu sistemde, Cumhurbaşkanı yürütmenin hem hukuki hem de fiili olarak başında bulunmaktadır. Yani maliye politikasının başarısından da Cumhurbaşkanı sorumludur. Oysa Meclis Bütçe Komisyonunun, Merkezi Yönetim Bütçesi üzerinde neredeyse sınırsız değişiklik yetkisine sahip olması ve yeni sistemde de Cumhurbaşkanının bütçe kanununu veto yetkisi olmaması, Cumhurbaşkanına ait maliye politikasının Meclis tarafından tıkanması tehlikesini de bünyesinde barındırmaktadır. Çalışmada, özellikle temsili demokrasi bağlamında Parlamentonun bütçe hakkı çerçevesinde, yeni hükûmet sisteminin bu potansiyel sorunları ele alınmış ve çözüm önerilerinde bulunulmuştur.
\end{abstract}

\section{Giriş}

Türkiye, uzun yıllardır tartışılan Başkanlık Sistemine, 24 Haziran 2018 Cumhurbaşkanlığı seçimiyle "Cumhurbaşkanlığı Hükûmet Sistemi" adıyla resmen geçmiştir. Yeni sistemle Başbakanlık ve bildiğimiz anlamda Bakanlar Kurulu kalkmış, yerine Cumhurbaşkanlığı Kabinesi ihdas edilmiştir. Yine Kalkınma Bakanlığı, Ekonomiden Sorumlu Bakanlık, Bütçe ve Mali Kontrol Genel Müdürlüğü ilga edilmiş; Hazine Müsteşarlığı Maliye Bakanlığı ile birleştirilerek Hazine Maliye Bakanlığı (HMB) halini almış, Gelir Politikaları Genel Müdürlüğünün adındaki "Politikaları" ifadesi "Düzenlemeleri" sözcüğü ile değiştirilmiş, Cumhurbaşkanlığına bağı birçok Kurul ve birimin yanı sıra Strateji ve Bütçe Başkanlığı (SBB) kurulmuştur. Bundan böyle Merkezi Yönetim Bütçe Kanunu (MYB) ve Kesinhesap Kanunu (KHES) süreçleri, Cumhurbaşkanlığı bünyesinde ve HMB ile SBB'nın koordinasyonu ile sürdürülecektir.

Siyasi partiler (iktidar partisi artık olmadığından) Bütçe Komisyonunda Meclis'teki temsilleri nispetinde yer alacaklardır. MYB ve KHES bundan böyle Bakanlar Kurulu Tasarısı olarak değil, Cumhurbaşkanlığı Teklifi şeklinde TBMM'ne sunulacaktır. 
Cumhurbaşkanının aynı zamanda siyasi parti genel başkanı olmasının önündeki engeller kaldırıldığından, ilginç biçimde, MYB ve KHES de dahil, Meclis'te kabul edilen tüm kanunlar bir siyasi parti genel başkanının onayına gidebilecektir. Daha da ilginç olan ise MYB ve KHES örneklerinde, Cumhurbaşkanının kendi kanun tekliflerine nihai onayı yine kendisinin verecek olmasıdır. Özellikle yürütmenin başı olarak, TBMM aracılığıyla millete hesap verdiği KHES sürecinin neticesinde, verdiği hesabı nihai olarak kendisinin onaylaması, diğer bir deyişle "kendi kendisiyle ibralaşma" görüntüsü dikkate değerdir. Yine, kanunlarında belirtilen yukarı ve aşağı sınırlar dahilinde vergi oranlarında değişiklik yapma yetkisinin bir heyet (mülga Bakanlar Kurulu) yerine tek bir kişiye (Cumhurbaşkanına) devredilmesi de önemli bir değişiklik olmuştur. Özellikle, mali açıdan Cumhurbaşkanlığını da denetleyen Sayıştay'ın Başsavcısının Cumhurbaşkanınca atanması, yeniden atanmasının Cumhurbaşkanının takdirinde olması, görev süresinin Cumhurbaşkanının görev süresi ile sınırlı olması; gerek hakimsavcı teminatı, gerekse TBMM adına denetim yapan bir kurumun en önemli memurlarından birinin TBMM dışından bir makam tarafından atanması görüntüsü itibariyle ilginç olmuştur.

Bu çalışmada yukarıda bazıları vurgulanan ve CHS'ne geçiş ile birlikte gündeme gelme potansiyeli taşıyan birçok uyumsuzluk, soru ve sorun ele alınarak, bunların bütçe hakkına, Cumhurbaşkanının maliye politikası hakkına ve nihayetinde temsili demokrasiye olası etkileri değerlendirilmiş ve bunları gidermeye yönelik bazı çözüm önerilerinde bulunulmuştur. Bu kapsamda, çalışmanın birinci kısmında "bütçe hakkı" olgusu tarihsel bir perspektiften ele alınarak, demokrasi ile olan derin ilişkisi ortaya konmuştur. İkinci kısımda bütçe hakkına kaynaklık teşkil eden bütçe kanunlarının kendilerine özgü nitelikleri vurgulanmıştır. Son kısımda ise CHS'nin potansiyel sorun ve uyumsuzlukları ele alınmış, bunların çözümüne yönelik bazı öneriler sunulmuştur.

\section{Bütçe Hakkı ve Egemenlik İlişkisi}

Siyasal egemenlik kavramı dışında, farklı bir bakış açısından, Çağan (2008: 183) "mali egemenlik" kavramını kullanmıştır. Buna göre "[m]ali egemenlik, egemenliğin mali alandaki görünümü olup onun ayrılmaz parçasıdır. Mali egemenlik, vergilendirme, harcama, bütçe yapma, borçlanma ve kamu mallarını yönetme yetkilerini içerir". Ancak bize göre bu kavram ontolojik olarak ve içerik açısından sorunludur. Vergilendiremeyen, bütçe yapamayan, kamu mallarını yönetemeyen bir güce toplumun rıza göstermesi, veya tersinden ifade edecek olursak, böyle bir gücün "egemen" olması, mümkün değildir. Egemenlik, kesinlikle rızaya ve bu rızanın temsiline dayalı bir olgudur.

Bu çerçevede, milletin kendi rızasıyla kılıç kullanma tekelini verdiği devletin, geri dönüp milletle/toplumla kurduğu ilk ilişki doğal olarak "kılıç" iledir. Bu el koyma ilişkisinin düzenli hale geldiği sisteme ise "vergi" denmektedir. Yani devletin toplum ve bireyle ilişkisinde kullandığı ilk araç kılıç, ikincisi ise vergidir. İşte vergilemenin sınırları ve gerektiğinde kılıç zoruyla (zor kullanarak) tahsili meselesi, bizi bütçe hakkı olgusuna götürmektedir. 
Zamanın Muhasebat Umum (Genel) Müdürü Faik B., 1930 tarihli "Bütçe ve Muhasebei Umumiye İzahları" adlı kitabında "bütçe hakkı" kavramını kullanmadan bu hakkın ne olduğunu ve kime ait olduğunu şöyle belirtmiştir (Türkçenin ve noktalama işaretlerinin o zamanki kullanımına/kullanılmayışına dokunmadık):

"Vergiyi ödeyen milletin ona razı olması ve milletten alınan vergilerin nerelere sarfedileceğini milletin tayin ve mürakebe eylemesi milletlerin hakkıdır. Iptida vergilerde milletin rızası alınmak lazımgeleceğini hükümdarların kabulile tecelli eden bu millet hakkı milletler ile hükümdarlar arasında kanlı birçok mücadelattan sonra masrafların da millet tarafından tasdik ve mürakabesinin kabul ve ilanı suretiyle tamamlanmıştır.

Müstebit hükümdarlar, halkın umumî hizmetlerinin ifası için verdiği paraları şahsî iratları telâkki etmekte, bu paraları birinci derecede zevk ve sefahatlarına ve ikinci derecede de gelişigüzel bazı devlet hizmetlerinin ifası uğrunda sorgusuz, mürakabesiz sarf etmekte idi. ... Bu hükümdarların bütün halka aşikâr olan bu tarzı hareketleri milletlerde saltanatlara karşı ihtilâl ve inkılâp hareketlerini uyandırmış, milletlerin çok haklı olan bu mübarezeleri neticesinde saltanatlar, istipdatlarıyla birlikte yıkılmıştır. Milletler; bu zaferlerini halkın kazancından, iradından ayırarak umumi hizmetlerin ifası için mukaddes borç bilerek verdiği paraların kendi müntehap ve mümessilleri tarafından mahalli istimalinin tayin olunması ve aynızamanda bu mümessiller marifetiyle mürakebe edilmesi kudret ve selâhiyetlerini ihraz ve istihsal etmişlerdir. Bu düsturlar teşkilatı esasiye kanunlarına konulmuş ve büyük bir hassasiyet ve kıskançlıkla muhafaza olunmuştur. Işste 'bütçenin' devlet hayatına tatbikatı bu avamilin tesiri altında, milletlerin çok pahalıya mal olan büyük mücadeleleri neticesinde elde edilmiş ve inkılâpların umdesi 'Hakimiyeti Milliye'ye müstenit teşekküllerin gaye ve vasfı mümeyyizi olarak muhafaza edilmiştir. Bundan dolayıdır ki Millet Meclislerinin en mühim ve esaslı mes'elesini "bütçe'lerin tetkik ve müzakeratı safahatı teşkil etmektedir ..." (ss. 4-5).

Görüldüğü gibi burada bir devlet egemenliğinden ziyade, milletin egemenliği (Hakimiyeti Milliye) ve vergi toplanarak harcama yapılmasına rızası söz konusudur. Yani bütçe hakkının kaynağı devlet egemenliği değil, o egemenliğin tecessüm ettiği hükümdar/hükümrana karşı gelişen isyanlar, o egemenlik karşısında verilen demokratik mücadelelerdir. Gösterilen uzun ve kanlı direnişlerin ardından milletler, temsilcileri (parlamento üyeleri) aracılığıyla, daha sene başlamadan, hükümranın sınırsız vergileme ve harcama yetkilerini "sınırlandırma" (tahdit) hak ve yetkisini elde etmişlerdir. Bu bakımdan, toplumların demokrasi mücadeleleri tarihi, aynı zamanda bütçe hakkına yönelik haklı isyan ve arayışların tarihidir. Dolayısıyla, millet egemenliğinin tecelligâhı olan parlamentolara ait bütçe hakkına yönelik her müdahale veya kısıtlama, aynı zamanda bir demokrasi sorunu olarak kendini göstermektedir. Bütçe hakkına tecavüz, demokratik yapının da zayıflaması anlamına gelecektir. Bu çalışmada, bütçe hakkı meselesini demokrasi olgusuyla birlikte ele almamızın temel gerekçesi de budur. Parlamentonun bütçe hakkının düzeyi, bir ülkede aynı zamanda demokrasinin de düzeyini göstermektedir.

Kamu hizmetleri ile bu hizmetlerin yapılmasını (harcamaları) sağlayacak kamu gelirlerinin toplanması hakkında karar verme yetkisi anlamına gelen bütçe hakkını, parlamentolar uzun mücadeleler sonunda elde etmişlerdir (Tüğen, 2018: 2). Bütçe 
hakkına yönelik ilk yazılı belge olan Magna Carta'dan (1215- Britanya ${ }^{2}$ ) bu yana bu süreç üç aşamalı olarak işlemiştir: İlk olarak, yukarıda da belirttiğimiz gibi hükümranın vergileme yetkilerinin, kapsamının ve miktar/oranı'nın sınırlandırılmasına yönelik parlamentoların yetki kazanması süreci gelmiştir. İkinci olarak, devlet harcamalarının parlamento onayından geçme zorunluluğu getirilmiştir. Son olarak ise, gelir ve giderlerin yıllık bazda parlamento onayından geçmesi kural haline getirilmiştir (yıllık olma ilkesi).

Parlamentonun bütçe hakkı elbette bunlarla sınırlı değildir. Yukarıda Faik B.'den yaptığımız alıntıda altı çizili olan "mürakebe" (denetim, teftiş) sözcüğü, esasen bütçe hakkının kullanımının da özünü oluşturur. Yani kamu gelir ve giderlerinin, gerek bütçenin kanunlaşması sürecinde, gerekse bütçenin uygulanması sırasında ve uygulanma sonrasında parlamento veya parlamento adına denetim yapan birimlerce mürakabe edilmesi bütçe hakkının esasıdır. Kısaca "bütçe hakkının kullanımı bütçe hazırlık, onay, uygulama ve denetim aşamalarında oluşmaktadır" (Selen \& Tarhan, 2014: 3). Devlet bütçesini konu alan metinlerde, genelde, bütçenin kanunlaşma sürecinde bütçe hakkının kullanımına vurgu yapılır. Oysa bütçenin uygulanması sırasında ve sonrasındaki denetimler de bütçe hakkına dairdir. Hassaten bütçenin kanunlaşma süreci, başlı başına bir mürakabe örneğidir. Çünkü birçok demokratik ülkede parlamentoların, yürütmenin sunduğu bütçe tasarısında önemli oranda değişikliğe gitme hakkı vardır. Diğer yandan parlamentodaki bütçe görüşmeleri de, kamuoyu önünde gerçekleşmesi hasebiyle, oldukça güçlü bir denetim sürecini ifade eder. Bütçe uygulandıktan sonra da, Kesinhesap kanunlarının ve parlamento adına denetim yapan kurumlarca yazılan denetim raporlarının parlamentoda görüşülmesi, tamamen bütçe hakkı kullanımının birer yansımasıdır.

Bütçenin uygulanması sırasında ise, yolsuzluk vs. gibi sıra dışı durumlar haricinde, parlamentolar genelde oldukça sınırlı bir bütçe denetimi ortaya koyarlar. Bunun nedeni ise parlamentonun bütçe hakkı olduğu kadar, yürütme görevini icra eden makamın da "maliye politikası hakkının" olmasıdır. Elbette parlamentonun bütçe hakkını savunmak her bütçe teorisyeninin doğal refleksidir. Fakat mutlak monarşi karşısındaki mücadeleler sonucu elde edilen bu hakkın, seçilmiş iktidarların maliye politikası oluşturma ve uygulama hak ve yetkisini olumsuz etkileyecek vurgulara sahip olmaması gerekmektedir. Aksi takdirde, "temsili demokrasi krizi" şeklinde tanımlanan, yüzyılın siyasal krizi daha da derinleşecek, hükumetlerin etkin olarak iktisat ve maliye politikası uygulaması daha da zorlaşacaktır (Akbey, 2014: 19). Ayrıca, şurası açıktır ki 1940-1980 [Keynesyen] döneminin etkisiyle, bütçe hakkı olgusu, günümüzde, büyük oranda katı biçimde yorumlanabilmektedir. Temsili demokrasilerde bir monarkın varlığından söz edilemeyeceği [edilse bile, sembolik bir konumda oldukları] halde, harcama ve vergi salma yetkisinin parlamenter denetimle sınırlandırılması anlaşılır bir

\footnotetext{
${ }^{2}$ Avam Kamarasına giden kamuya açık yolda yürüyen birisi, Sör Thomas More ve Lordlar Kamarasının diğer üyelerinin resimlerinin yanı sıra VIII. Henry döneminde Lordlar Kamarası Başkanı olan Cardinal Wolsey'in büyük bir resmi ile karşılaşmaktadır. Resmin altında şöyle bir yazı vardır: “Avam Kamarasının Başkanı olan Sör Thomas More, Cardinal Wolsey'in verdiği emre rağmen vergi görüşmeleri olmaksızın Kral VIII. Henry'e devlet desteği vermeyi reddeder." (Bacon, 2008: 230).
} 
durumdur. Ancak, parlamento tarafından belirlenen sınırlar dahilinde, bütçe kompozisyonu içinde, değişiklik yapma yetisinin tanınması da, genelde iktisat, özelde ise maliye politikası uygulama hakkının bir gereği olmalıdır. Seçilmiş temsilcilerin sınırlandırma ve denetim yetkileri olduğu kadar, siyasal duruşu ve ilkelerinin ve ayrıca parti programının sonucu olarak, hükumetlerin de politika uygulama hakkı vardır. Bu açıdan hükumete, bütçe uygulamaları açısından gerekli esneklik sağlanmalıdır (Akbey, 2014: 21). Ancak bunun Anayasal ve yasal sınırları net bir şekilde ortaya konmalı; ayrıca, bu esnekliğin geri dönüp parlamentonun bütçe hakkını fiili veya yasal olarak etkisiz hale getirmesi (yani bütçe hakkının kısmen yahut külliyen gasp edilmesi) engellenmelidir. Çünkü, "yürütmenin parlamentonun [belirli alanlara] tahsis ettiği bazı fonlara rahatça el koyabilmesi, bütçenin bölümleri arasında çok rahat aktarma yapabilmesi ve parlamentonun onayı dışında kolayca yeni kaynaklar bulabilmesi; parlamentonun bütçe üzerindeki [bütçe hakkından kaynaklanan] denetimlerini de zayıflatacaktır" (Wehner, 2006: 770). Burada bütçe hakkı ile maliye politikası hakkı arasında optimum bir dengenin sağlanması elzemdir.

\section{Bütçe Nedir ve Bütçe Kanunu Neden Farklıdır?}

Merkantilizmden Keynesyen refah devleti modeline, oradan da, 2008 krizi sonrasında neo-merkantilizme uzanan süreçte, kamu sektörü; gerek harcama ve gelir yapısı, gerek yatırımları ve gerekse de bütçe kompozisyonu ve sistemiyle, gerçekten de ekonominin en temel sürükleyici aktörü olmuştur. 1929 krizi öncesi ve 1980 sonrası kısa liberal (ve neo-liberal) dönemler dışında, ekonominin başat unsuru kamu sektörü olmuştur. Hal böyle olunca, kamu bütçesi de bütün klasik ve çağdaş fonksiyonlarıyla (iktisadi/mali etki, kalkınma, istikrar, özel sektörü telafi etme, gelir dağılımını düzenleme vs.) birlikte, hem toplam talep fonksiyonunun en temel ve belirleyici bileşeni olmuş, hem de sabit ve beşeri sermaye (eğitim, sağlık gibi) yatırımlarıyla, ekonomideki sermaye birikimine çok önemli katkılar yapmıştır.

Esasen bütçesiz bir iktidarı tahayyül etmek neredeyse imkansızdır. Şayet antropolojik manada ortada bir "iktidar" ve aynı zamanda parasal bir değiş-tokuş düzeni (kıymetli madenler dahil) varsa, bu iktidara ait varidatın zamanla, "bütçe" ile ifade edilen ve kayıt altına alınan bir yapıya dönüşmemesi mümkün değildir. Her iktidar bir gün bütçe yapacaktır, çünkü modernleşme süreci içerisinde bütçesiz (yıllık bütçeler hazırlamayan) bir hükumet, teknik anlamda yok hükmündedir.

Bir ekonomi sürekli cari fazla ve bütçe fazlası veriyor olsa bile (yani hazine dolup taşsa bile) bütçe yapılması mukadderdir. Faize dayalı parasal kapitalist sistemde; yatırıma, menkule (mevduat, altın hesabı vd.) veya gayrimenkule dönüşmeyen her değer zamanla yok olmaya mahkûmdur. Çünkü sistem faize dayalı ve parasaldır ve bu yüzden düşük oranlı da olsa enflasyon kaçınılmazdır. Bundan dolayı, devlet malının pula dönüşmemesi için, kamusal kaynakların, milletin denetimi altında yıllık planlarla sarf edilmesi ve buna uygun olarak kamu gelirlerinin miktarına ve tahsiline her yıl yeniden cevaz verilmesi gerekmektedir. Bu açıdan, bir ekonomide en önemli iktisadi metin devlet bütçesidir. 
Bütçe, kelime kökeni olarak; Bulga, Bouge ve Bougette, Budget sözcüklerinden türemiştir. Gelin bu türeyişin hikayesini, zamanın Maliye Vekaleti Müsteşarı Cezmi Erçin'den okuyalım (Türkçenin ve noktalama işaretlerinin o zamanki kullanımına/kullanılmayışına dokunmadık) (Erçin, 1938: 4):

"Bütçe kelimesi, menşei latince olan Bulga kelimesinden naklen eski bir Fransız kelimesi olan Bouge veya Bougette kelimesinden gelmektedir. Be kelime, deri çanta demektir. Ingilizler bu kelimeyi Normandiyalılardan alarak Budge veya Budget şeklinde tahvil eylediler, ve kelimeye hususî bir mana verdiler. Vaktile ingilterede parlâmento içtimalarının sonuna doğru Avam Kamarası tahsisatları kabul edileceği sırada, Maliye Nazırı, içerisinde kanun projesi bulunan bir çantayı merasimle açmakta ve bu hareket 'para çantasının açılması' diye tavsif edilmekte idi. Bu çanta içerisinde parşömen kâğıdı üzerine tahsisat miktarları yazılmış bir vesika bulunmakta idi. Bu çanta ve vesika, Ingiliz imparatorluğunun nevama para çantasını, hazinesini temsil eylemekte idi. Bilâhare, Maliye Nazırı tarafından Avam Kamarasının Varidat Encümeni halinde içtimaı sırasında, Committee of Ways and Means'de verdiği nutuka da (Budget) veya (Budget speech) unvanı verilmiştir. Hattâ bugün bile Opening the budget tabiri, Ingilterede parlâmento ıstılahında bütçe kanununun projesine ait müzakerelere başlandığını ifade eylemektedir. Bütçe kelimesinin ifade ettiği mananın ingilterede umum umum tarafından kabule mazhar oluşu, ağlebi ihtimal, XVIII inci asırda vuku bulmuştur. ... Fransada bu kelime ilk defa resmen 1802 senesinde konsüller tarafından yazılan bir tamimde kullanılmıştır. 1806 senesinde (Budget de l'Etat) şeklinde kat'î olarak yerleşmiştir. ... Osmanlı imparatorluğunda ... [b]ütçe tabiri tanzimattan sonra ilk defa 1855 (1271) tarihinde tanzim kılınan nizamname başlığında (Bütçe nizamnamesi) ${ }^{3}$ görülür".

Peki bütçe nasıl bir metindir? Bir kanun mudur yoksa bir idari belge midir? Literatüre ve mevzuata bakıldığında oldukça farklı tanımların yapıldığı görülmektedir. Elbette bu tanım farklılıkları, tanımlayanların yanlış veya eksik değerlendirmelerinden değil, bütçenin aynı anda hukuki, mali, iktisadi ve siyasi işlevlere sahip olmasından kaynaklanmaktadır. Bütçe için kullanılan kavramlar: mali doküman, parlamento tasarrufu, kararname, nizamname, idari tasarruf, hukuki tasarruf, belge, mali nitelikli yasa ve nihayet kanun şeklindedir (Bkz. Feyzioğlu, 1969: 14; Gürsoy, 1981: 6; Tüğen, 2018: 2). Mali mevzuatımıza bakıldığında ise, mülga Muhasebe-i Umumiye Kanununda (md. 6) "kanun", 2018 sayılı Kamu Mali Yönetimi ve Kontrol Kanununda ise hem "belge" (md. 3/f) hem de "kanun" (md. 15-1) olarak tanımlanmıştır4.

Bu farklı tanımların sebebi, tanım yapanların eksikliklerinden değil, bütçenin farklı işlevleri ve nev'i şahsına münhasır hukuki konumudur. Bütçe, parlamentonun bütçe hakkından dolayı ve bağlayıcı olması için bir kanun olarak çıkarılmak durumundadır. Diğer yandan bu durum sadece Merkezi Yönetim Bütçesi (MYB)

\footnotetext{
3 Oysa Tüğen'e göre (2017: 16) 1855 yılındaki bu nizamnamenin tam adı “Hazine-i Celile Muvazene Defterinin Sureti Tanzimine Dair Nizamname” şeklindedir. Tüğen'e göre [Erçin'in 1855'te tanzim edildiğini ifade ettiği] nizamname 1872 yılında tanzim edilmiştir ve tam adı Devlet-i Aliyenin Bütçe Nizamnamesi'dir. O zamana kadar bütçe için “Muvazene Defteri” ibaresi kullanılmıştır.

4018 sayılı Kanun:

Md. 3: "Münhasıran bu Kanunun uygulanmasında; ... f) Bütçe: Belirli bir dönemdeki gelir ve gider tahminleri ile bunların uygulanmasına ilişkin hususları gösteren ve usulüne uygun olarak yürürlüğe konulan belgeyi, ... ifade eder".

Md. 15/1: Merkezî yönetim bütçe kanunu, merkezî yönetim kapsamındaki kamu idarelerinin gelir ve gider tahminlerini gösteren, bunların uygulanmasına ve yürütülmesine yetki ve izin veren kanundur".
} 
açısından geçerlidir. Bununla birlikte, kamu sektörü sadece MYB kapsamındaki (Genel Bütçeli İdareler, Özel Bütçeli İdareler ve Düzenleyici Denetleyici Kurumlar) idarelerden oluşmamaktadır. Örneğin belediyeler, döner sermaye işletmeleri, KiT’ler, TCMB gibi diğer kurumlar da mevcuttur. Ancak devletin adem-i merkezi örgütlenmesi gereği bunların bütçelerini kendilerinin yapması gerekmektedir. Kanun yapma yetkisi yalnızca ve münhasıran TBMM'de olduğuna göre, MYB dışında yer alan bu kurumların hazırladıkları bütçeleri birer "kanun" olarak tanımlamak imkansızdır. İşte bu yüzden bunlara "tasarruf, kararname, mali doküman, nizamname" gibi adlar verilmektedir.

Bir kanun olarak kabul edilse bile, Bütçe Kanununu; süreç, yapı, içerik, uygulama ve uygulama sonrası gibi unsurlardan hareketle, diğer kanunlar gibi düşünmemek gerekir. Zira bütçe kanunu birçok yönden diğer kanunlardan ayrışmaktadır. Bütçe kanunu ile normal bir kanun arasındaki farklılıklara baktığımızda:

a. Öncelikle; korunacak inkılâp kanunlarının sıralandığı "Çeşitli Hükümler" başlığı, "Geçici Hükümler" başlığı ve "Son Hükümler" başlığı hariç Anayasanın asıl ana metninde yer alan ve adı doğrudan zikredilen kanunlar yalnızca Bütçe ve Kesinhesap Kanunlarıdır. Diğer kanunlarla ilgili düzenlemelerden Anayasada bahsedilirken, kanun ismi belirtilmeden; "kanununda belirtilen", "kanunun cevaz verdiği", "kanununun öngördüğü" şeklinde ifadelere yer verilir. Oysa Anayasada, Bütçe ve Kesinhesap Kanunlarının doğrudan isimleri yazılmıştır.

b. Bütçe kanunu her mali yılbaşından önce yeniden hazırlanmak ve TBMM'de onaylanmak durumundadır. Oysa diğer kanunlar açısından böyle bir zorunluluk bulunmamaktadır. Örneğin Türk Ceza Kanunu veya Kabahatler Kanununu yer yıl yenileme mecburiyeti söz kokusu değildir.

c. Bir önceki maddenin devamı olarak, yeni mali yılın başında bir önceki yılın bütçe kanunu kendiliğinden yürürlükten kalkmaktadır. Yeni mali yıl kanununa bu konuda bir hüküm koymaya (örneğin 2019 mali yılı bütçe kanununa "2018 yılı MYB kanunu yürürlükten kaldırımıştır" gibi bir madde eklemeye) gerek yoktur. Buna karşılık diğer kanunlarda bu bir zorunluluktur. Örneğin yeni bir Belediyeler Kanunu yürürlüğe girdiğinde, bir öncekini yürürlükten kaldırmak zorundadır. Eğer önceki kanunun bazı maddeleri yürürlükte kalacaksa da bu açıkça belirtilmelidir. Bütçe kanununda ise bir önceki kanun otomatik olarak yürürlükten kalkar; bir önceki bütçe kanununun bazı maddelerinin yürürlükte kalması ise mümkün değildir.

d. Bütçe kanunu, ekli cetvelleri olmadan hiçbir anlam ifade etmez. Çünkü her kurum için tahsis edilen ödenekler, bütçe kanununa ekli (A) cetvelinde, Genel Bütçe gelirleri ise (B) cetvelinde gösterilir. Genel Bütçe dışındaki kurumların gelirleri ise, (A) cetvelinde kendi ödeneklerini gösteren tablodan sonra gelirler tablosu halinde (yani MYB'nin A cetveli içinde yer alan B cetvelleri şeklinde) gösterilmektedir. Dolayısıyla, bütçe kanun metni toplamların ifade edildiği düz bir metin olduğundan, bu cetveller olmadan, harcamacı kurumların cari yılda hangi kaleme ne kadar harcama yapabileceklerini veya hangi kaleme ne kadar gelir tahsil edebileceklerinin tahminini görmek olanaksızdır. Diğer kanunlarda ise sadece intiyaç duyulan konularda kanun metnine örnek form, çizelge veya cetvel eklemek yeterlidir. İhtiyaç yoksa, hiçbir belge, tablo veya cetvel eklenmeyebilir.

e. Benzer şekilde, bütçe kanun teklifine, Orta Vadeli Malî Planı da içeren Bütçe Gerekçesi, Yıllık Ekonomik Rapor gibi yasal olarak eklenmesi zorunlu belge ve cetveller söz 
konusudur. 5018 sayılı KMYKK'nun 18 inci maddesinde bu belgeler tek tek sıralanmıştır. Başka hiçbir kanun açısından bu şekilde belge-cetvel-rapor ekleme zorunluluğu yoktur.

f. Bütçe kanunu, kamu gelirlerine yasal dayanak teşkil eden mevzuatı her yıl yeniden harekete geçirmektedir. Bütçe kanununa ekli (C) cetvelinde, kamu gelirlerinin dayanağı olan kanun, KHK ve diğer mevzuat tek tek sayılmaktadır. Bu cetvelde yasal dayanağı zikredilmeyen hiçbir kamu geliri, ilgili bütçe yılında tahsil edilemeyecektir. Örneğin 2019 yılı MYB Kanunu (C) cetvelinde Gelir Vergisi Kanununun adı yer almadığında, 2019 yılında gelir vergisi toplamak imkansız hale gelmektedir. Böyle bir güç ve imtiyaz, bütçe kanunu dışında hiçbir için söz konusu değildir.

g. Bütçe kanununu sadece iktidardaki yürütme organı (eski sistemde Bakanlar Kurulu, yeni sistemde Cumhurbaşkanı) parlamentoya teklif edebilir. Oysa diğer kanun ve değişiklik teklifleri (Türkiye için) bir veya daha fazla milletvekilinin imzasıyla verilebilir. Yürütmeye sadece bütçe kanunu konusunda böyle bir imtiyaz verilmiştir.

h. Normal bir kanunun, ilgili komisyona havale edildikten sonra, en geç 45 gün içinde sonuçlandırılarak Meclis Başkanlığına sunulması gerekir. Başkanlık, talep üzerine bunu en fazla 10 gün daha uzatabilir (TBMM İçtüzüğü, md. 37). Bütçe kanunu ise Anayasal hüküm gereği (AY md. 161/3) 55 gün boyunca Bütçe Komisyonunda görüşülebilir. Ek süre ise mümkün değildir.

i. Normal bir kanun parlamentoda maddeler halinde görüşülür. Bütçe kanunu ise kanun metni açısından maddeler halinde görüşülür ve oylanır, gider (A cetveli) ve gelir (B cetveli) cetvelleri açısından da "bölümler halinde" (her harcamacı kurumun gider bütçesi fonksiyonel sınıflandırmanın birinci düzeyine göre, özel bütçeli kurumlar ile düzenleyici ve denetleyici kurumların $\mathrm{B}$ cetvelleri ise kendilerine ait A cetvellerinden sonra ekonomik sınıflandırmanın birinci düzeyinde) oylanır. Yani bütçe kanununda sadece maddeler halinde onama değil, "madde ve bölümler halinde onama" söz konusudur. Başka hiçbir kanunda böyle bir uygulama söz konusu değildir.

j. TBMM tarafından kabul edilmiş bütçe kanununu, Cumhurbaşkanının geri gönderme yetkisi yoktur. Anayasanın 89 uncu maddesinin 2 nci fıkrasında "[y]ayımlanmasını kısmen veya tamamen uygun bulmadığı kanunları, bir daha görüşülmek üzere, bu hususta gösterdiği gerekçe ile birlikte aynı süre içinde [15 gün içinde -F.A.], Türkiye Büyük Millet Meclisine geri gönderir. Cumhurbaşkanınca kısmen uygun bulunmama durumunda, Türkiye Büyük Millet Meclisi sadece uygun bulunmayan maddeleri görüşebilir. Bütçe kanunları bu hükme tâbi değildir." hükmü yer almaktadır. Yani Cumhurbaşkanı, önüne gelen her kanunu bir daha görüşülmek üzere TBMM'ye geri gönderme yetkisine sahipken, bütçe kanununu onaylamak zorundadır. Bu da sadece bütçe kanunlarına tanınan bir imtiyazdır.

k. Anayasanın 161 inci ve 5018 sayılı Kanunun 42 nci maddeleri gereği, diğer kanunlardan farklı biçimde, bütçe kanununun uygulama sonuçları ayrı bir kanun olarak (Kesinhesap Kanunu) TBMM'de görüşülüp oylanarak karara bağlanır. Her mali yılın bütçe kanunu, uygulandıktan sonra, bir kesinhesap kanunuyla yeniden onanmak durumundadır. Başka hiçbir kanun için böyle bir yasama denetimi söz konusu değildir. Örneğin iş̧ Kanunu yürürlüğe girdikten sonra, yürürlükte kalır ve her yıl yeniden yeni bir değerlendirme kanunuyla onanmasına gerek yoktur. Bu durum sadece bütçe kanunu açısından geçerlidir. 
I. Bütçe kanunu, anayasal olarak "Geçici"si olan tek kanundur. Örneğin bir "Geçici Medeni Kanun" söz konusu olamazken, Geçici Bütçe Kanunu, doğrudan Anayasanın 161 inci maddesi hükmü gereği, ihtiyaç duyulduğunda hazırlanması lüzumlu olan tek "geçici" kanundur.

m. TBMM, diğer kanunların uygulama sonuçlarını Anayasa Mahkemesi veya normal yasama denetim yöntemleri (Meclis araştırması, genel görüşme, Meclis soruşturması ve yazılı soru) yoluyla denetler. Bütçe kanunlarını da bu araçlarla denetleyebilir, ancak buna ek olarak, TBMM, kendisi adına denetim yapan Sayıştay aracılığıyla bütçe kanununun uygulanmasını ayrıca denetler. Sayıştay, münhasıran, bütçe kanununun (ve bütçesel hükümler içeren diğer kanunların -örneğin, harcamacı kurumun Harçlar Kanununa istinaden tahsil etmesi gereken harçları tahsil edip etmediğini) uygulanmasının denetlenmesi ile görevlendirilmiştir (elbette Genel Yönetim kapsamındaki diğer idarelerin ve KiT'lerin de bütçe denetimini yapar ancak konumuz itibariyle bunları dışarıda tuttuk). Bu açıdan, diğer kanunların getirdiği yargılama süreçlerinden farklı olarak, TBMM adına, "hesap yargılaması" adı taşıyan, Sayıştay’a has bir yargılama gerçekleştirir.

n. Bütçe kanunu ile diğer kanunlarda değişikliğe gidilemez. Normalde bir kanuna konan bir madde ile başka bir kanunda değişikliğe gidilebilir. Örneğin İş Kanununa konacak bir hükümle Türk Ceza Kanununun bir maddesi değiştirilebilir. Fakat bütçe kanununa konacak bir madde ile örneğin İş Kanununda veya 5018 sayılı KMYKK'nda bir değişiklik yapılamaz. Bunu sebebi ise AY'nın 87 nci ve 161 inci maddeleridir. 87 nci madde "Türkiye Büyük Millet Meclisinin görev ve yetkileri, kanun koymak, değiştirmek ve kaldırmak; bütçe ve kesinhesap kanun tekliflerini görüşmek ve kabul etmek ..." biçimindedir. 161 inci maddede ise (2 nci fıkranın son cümlesi) "[b]ütçe kanununa, bütçe ile ilgili hükümler dışında hiçbir hüküm konulamaz" denmektedir. Görüldüğü gibi 87 nci maddede bütçe kanunu diğer kanunlardan ayrılmış, 161 inci maddede ise bütçe kanununda sadece bütçe ile ilgili konuların yer alabileceği hükme bağlanmıştır. Dolayısıyla mali konuları düzenleyen kanunlar dahil, bütçe kanunu ile hiçbir kanunda değişikliğe gidilemez.

o. Bir önceki madde ile bağlantılı olarak, bütçe kanunları başka kanunlarda değişikliğe gitmedikleri veya bütçe ile ilgisiz hüküm içermedikleri sürece Anayasa Mahkemesince kısmen veya tamamen iptal edilemezler. Anayasa Mahkemesini farklı tarihlerde verdiği kararlar da bu yöndedir (Bu konuda derinlemesine yapılan bir tartışma için bkz. Yüksel, 2007).

Özetle, her ne kadar adı "Kanun" olsa da, bütçe kanunu birçok yönden diğer kanunlardan farklılık arz eder. İşte bu yüzden, maliye ve bütçe literatüründe, bütçenin bir kanun olup olmadığına yönelik ciddi tartışmalar yaşanmıştır. Esasen bu tartışmalar oldukça eskiye dayanmaktadır. Örneğin, Cezmi Erçin, müsteşar olmadan önce, 1937 yılında henüz Maliye Vekaleti Mali Tetkik Heyeti Reisi iken kaleme aldığı "Hukuki Bakımdan Bütçe" adlı kısa eserinde (sonrasında aynı 1938 tarihli çalışmasında da aynı görüşleri dercetmiştir) kendi yorumunu ortaya koymaktadır (Türkçenin ve noktalama işaretlerinin o zamanki kullanımına/kullanılmayışına dokunmadık):

"... [V]ergilerin, bütçe kanunu ile her sene tarh ve cibayetine mezuniyet verilen memleketlerde ... bu vergileri tadat ve beyan eden; tahsillerine mezuniyet ve salâhiyet veren bütçenin, aynı vaziyette bulunan şahısların cümlesine tatbik edilecek hükmü ihtiva eylemesi itibarile, kanuniyeti lazımgelir. Varidat bütçesinin faraza, devlet emlâkinden 
elde edilecek hasılata taallûk eden kısmı ise, idari bir muameleden ibarettir. ... Bütçenin asla bir kanun olmadığını söyleyenlere gelince, bunlar varidat ve masraf bütçelerini ayırmaksızın, vergilerin senelik olması prensibi kabul edilmiş olsun olmasın, bütçenin bir kanun mahiyetini haiz olamıyacağı kanatındadırlar. ... [B]ütçe, bir idari plandır, bütçenin tesbiti bir idarî muameledir; ... idari bir hükmü ihtiva eder, idarî makamata verilen bir emir ve vekalettir; ... devletin senelik varidat ve masraflarını tahmin eylemeğe kanun demek tamamen manasızdır ...(ss. 12-14). ... Bence, bütçenin materiyel veya formel manada bir kanun olup olmadığı şeklinde uzun zaman devam etmiş olan münakaşaları bir tarafa bırakarak, bütçe kanununu, kendi sahasındaki bütün hususiyetlerile mütalâa etmelidir. Bütçenin diğer kanunlarla mukayesesi suretile ne nazarî ne amelî bir neticeye vâsıl olunamaz (s.23)" (Erçin, 1937: 12-14, 23).

Görünen o ki Erçin bu tartışmanın neticesinde kati bir karara varamamıştır Benzer şekilde Ordinaryüs Prof. Fazıl Pelin de 1944 tarihli "Finans İlmi: Bütçe" adlı çalışmasında, bu tartışmayı bir neticeye vardırmamıştır. Pelin; "[b]ütçenin Meclisin tasdikinden geçmek itibarile şeklen kanun olduğunda şüphe yoktur. Fakat acaba maddeten, cevheri, hukukî muhteviyatı itibarile de bir kanun mudur? Ortaya objektif mahiyette bir hukuk kaidesi, umumî ve imperatif hükümler koyuyor mu? Bu bapta hukukçular birbirile ihtilaf halindedir" (s. 6) dedikten ve bazı hukuk teorisyenlerin tespitlerinden hareketle, bütçe gelir ve giderlerinin tahmin ve tahsisine yönelik Erçin'inkine benzer ayrımları ortaya koyduktan sonra "[i]şte bu telakkiler ekser hukukçuları bütçenin muhteviyatı itibarile değil yalnız şeklen bir kanun olduğu neticesine götürmüştür" (s. 7) diyerek meseleyi bağlamıştır.

Illginç biçimde, devlet bütçesiyle ilgili sonradan yapılan çalışmaların birçoğunda bütçenin bir kanun olup olmadığı tartışmalarına pek fazla değinilmemiş; değinen çalışmaların bir kısmında yine nihai bir görüş ortaya konmamış (örneğin Batırel, 1987: 6), görüş ortaya koyanlar da tercihlerini "diğer kanunlardan farklı özellikler gösteren bir kanundur" mealinde ifade etmişlerdir. Örneğin Gürsoy (1981: 62-63) “... Bütçe Kanununun hukuki değeri hakkında yapılagelmiş ... tartışmalar, nazari planda kalmaya mahkum görüşlerdir. Söylenenler hukukçuların meclis tasarrufları hakkındaki farklı görüşlerini yansıtır. Anayasa bütçeden 'kanun' diye söz ederken, Genel Muhasebe Kanunumuz onu 'kanun' diye tanımlarken, Bütçenin Kanun olup olmadığı hakkında şüphe uyandıracak görüşler ortaya atmak gereksizdir, abestir. ... 'Bütçe Kanunu' önemli hukuki sonuçlar doğuran 'gerçek anlamıyla' bir kanundur. Ona başka gözle bakmak, hukuki bazı incelikleri ortaya koymuş olsa bile, gerçeği yansıtmaz" diyerek, adeta teorisyenlere serzenişte bulunmuştur.

Benzer şekilde Mutluer vd. (2005: 77) "[k]anımızca, bütçe kanunlarını diğer kanunlardan ayıran bazı farklılıklar bulunmasına rağmen, bunları kanun olarak kabul etmek gerekir. Çünkü, bütçe gelir ve giderlerinin parlamentodan geçirilerek onlara kanun niteliğinde hukukilik kazandırmak, her şeyden önce bütçe hakkının bir gereğidir. Böylece, bütçenin hem hukuki, hem de siyasi niteliği gerçekleşir"; Edizdoğan \& Çetinkaya (2014: 12) "[b]ütçe kavramının tanımlarında bir kanun, tasarruf ve belge olduğu teorisyenlerce tartışma konusu olmuş olsa da idare ve yargı organları yönünden bir kanun olduğu konusunda kuşku yoktur"; Tüğen (2018: 21) "[k]anunların taşıması 
gerekli bazı özelliklere ... sahip olmasa da bütçenin kanun olduğu genel kabul görmüştür. Çünkü bütçe de diğer kanunlar gibi anayasaya göre yürütme organı olan hükümet ya da Devlet Başkanı, Cumhurbaşkanlığı Hükümet Sisteminde Cumhurbaşkanı tarafından tasarı ya da teklif şeklinde hazırlanmakta, meclise sunularak görüşülmekte ve oylanmaktadır." şeklinde yorumlayarak, her ne kadar diğer kanunlardan ayrışan yönleri olsa da, bütçenin bir kanun olduğu görüşünde birleşmişlerdir.

Bize göre de bütçe "nev'i şahsına münhasır bir kanundur". Anayasa'da açıkça "kanun" olarak geçmesi, Meclis'te görüşülüp oylanması, Resmi Gazetede yayımlanması, bağlayıcı olması, Sayıştay'ın hesap yargılamasına esas teşkil edecek şekilde hukuki sonuçlar doğurması gibi özellikleri; bütçenin bir kanun olarak telakki edilmesi gerektiği soncunu doğurmaktadır. Ancak bu durum, bütçenin başta hükumetin (maliye) politika(sı) belgesi olması, harcama-gelir planlarını da içerecek biçimde aynı zamanda bir iktisadi/mali proje olması, MYB dışı devlet kurumlarında mecburen bir idari belge biçimini alması gibi gerçekleri göz ardı etmemizi gerektirmemektedir. Aynı zamanda, yukarıda bahsedildiği haliyle bütçe kanununun kendine özgü bir kanun olması, bir bakıma da, yürütmenin "maliye politikası" hakkı çerçevesinde, bütçe yapısı ve kompozisyonunun, iktisadi yapıdan ileri derecede etkilenmesi ve dahası iktisadi yapı ve süreçlere etki etmesinden kaynaklanmaktadır.

Bütçe Kanununun bu kendine özgü yapısı, parlamentonun yasama ile denetim hak ve yetkilerinin içerisinden "bütçe hakkının" ayrı bir başlık olarak öne çıkmasının da nedenidir. Parlamento her konuda kanun yapmakta ve denetim gerçekleştirmektedir. Ancak parlamentonun -örneğin- ceza kanunlarını yapma yetkisi için bir "ceza hakkı" kavramından söz edilmemektedir. Yine parlamentonun bir "insan haklarını inceleme hakkı" da münhasıran zikredilmemektedir. Buna karşılık, yukarıda bahsedilen özelliklerinden ötürü, "bütçe hakkı" parlamentolar ve demokrasiler için neredeyse olmazsa olmaz biçimde savunulmakta, gerek teoride gerekse anayasal/yasal olarak hukuk sistemi içerisinde güçlü bir şekilde vurgulanmaktadır.

\section{Cumhurbaşkanlığı Hükûmet Sistemi ve Bütçe Hakkı}

Türkiye'de 23 Nisan 1920'den bu yana uygulanmakta olan parlamenter hükûmet sistemi, 16 Nisan 2017 tarihinde yapılan Anayasa değişikliği referandumu ile sonlandırılmış ve 3 Kasım 2019 tarihinde yapılacak birleştirilmiş (milletvekilliği ve Cumhurbaşkanı) genel seçimlerle birlikte Cumhurbaşkanlığı Hükûmet Sistemine (CHS) geçilmesi öngörülmüştür. Ancak sonradan yaşanan siyasi gelişmeler neticesinde, seçim tarihi erkene alınmış ve 24 Haziran 2018 seçimleriyle bütünüyle yeni sisteme geçilmiştir. CHS'nin getirdiği tüm Anayasal, yasal ve idari değişiklikleri ortaya koymak, bu çalışmanın sınırları açısından mümkün değildir. O yüzden yalnızca "bütçe hakkı" ile irtibatları çerçevesinde bu değişiklikler ele alınacaktır. Yani Merkezi Yönetim Bütçesinin kanunlaşma, uygulanma ve denetlenme süreçlerinde; TBMM'ne tanınan bütçe hakkının bu değişimlerden ne şekilde etkilendiği analiz edilecektir. 


\section{1. "Tasarı"dan "Teklif"e: Merkezi Yönetim Bütçesinin Kanunlaşması}

Bütçenin "birlik" ilkesi gereği, tüm kamu gelir ve giderlerinin tek bir bütçede gösterilmesi, yeknesaklık ilkesi gereği de bütçedeki bölüm/kesim adedinin mümkün olduğunca az ve öz olması gerekmektedir. Ancak gerek devlet faaliyetlerinin çeşitlenmesi, gerekse demokratik teamüller (yerel yönetimlerin ve üniversitelerin mali özerkliği gibi) tüm kamusal harcama ve gelirlerinin tek bir "Genel Bütçe" ile gösterilmesini imkânsız kılmakta; Genel Bütçe dışında birçok bütçe uygulamasını da (Özel Bütçe, Düzenleyici Denetleyici Kurum Bütçesi, Sosyal Güvenlik Kurumları Bütçeleri, Mahalli İdare Bütçeleri, Kіт Bütçeleri, Döner Sermaye İşletme Bütçeleri, Bağımsız Bütçeli Kurumlar- TRT ve TCMB gibi-, Bütçe Dışı Fonlar ve Varlık Fonu) beraberinde getirmektedir. TBMM'de Kanunlaşan ise; Genel Bütçe, Özel Bütçeler ve Düzenleyici Denetleyici Kurum bütçelerinden oluşan Merkezi Yönetim Bütçesidir.

CHS öncesi; harcamacı kurumlar cari ve transfer ödenek tekliflerini Maliye Bakanlığı ile, yatırım ödenek tekliflerini ise Kalkınma Bakanlığı ile müzakere ederlerdi. Gelir Bütçesini ise Gelir Politikalar Genel Müdürlüğü münferiden hazırlar ve MYB Kanununa eklenmek üzere Bütçe ve Mali Kontrol Genel Müdürlüğüne (BÜMKO) gönderirdi. BÜMKO harcama ve gelir bütçelerini birleştirerek MYB Kanun Tasarısını oluşturur, Maliye Bakanının son gözden geçirmesinden sonra Başbakanlığa gönderirdi. Başbakanlıkça MYB Kanun Tasarısı imzaya açılır, tüm bakanlar imzaladıktan sonra, Tasarı TBMM Başkanlığına gönderilirdi.

MYB, Bakanlar Kurulunca "kanun tasarısı" olarak, mali yılbaşından 75 gün önce TBMM'ne sunulur, Bütçe Komisyonunda ve Genel Kurulda Maliye Bakanınca takdim edilir, Bütçe Komisyonunda en fazla 55 gün, Genel Kurulda ise en fazla 20 gün görüşüldükten sonra Cumhurbaşkanının onayına gider, Anayasanın 89 uncu maddesi gereği de Cumhurbaşkanınca zorunlu olarak onaylanarak resmi gazetede yayımlanır ve mali yılbaşından önce yürürlüğe girerdi.

Kırk üyeden oluşan Bütçe Komisyonunun yirmi beş üyesi iktidar partisine tahsis edilir, kalan üyeler de mecliste grubu bulunan siyasi partilere temsilleri nispetinde dağıtılırdı. Bütçe Kanun Tasarısı üzerinde Komisyon (gider artırıcı ve gelir azaltıcı olanlar dahil) her türlü değişikliğe gidebilirken; Genel Kurul aşamasında vekillerin gider artırıcı veya gelir azaltıcı öneride bulunamama, madde değişiklik önergelerinin görüşülmeden doğrudan oya sunulması gibi (hükûmetin maliye politikası hakkını gözeten) sınırlamalar söz konusuydu.

Yapılan Anayasal değişiklikle, Anayasada 161-164 üncü maddeler arasında yer alan bütçe ve kesinhesap ile ilgili hükümlerden bazıları kaldırılmış, kalan ve değişikliğe uğrayanlar ise tek maddede, 161 inci maddede, birleştirilmiştir. Buna göre, Milli Bütçe Tahmin Raporu, MYB Kanununa eklenmesi gereken belgeler arasından çıkartılmıştır. Ayrıca bütçede değişiklik yapmayı (bölümler arası aktarma yetkisini) düzenleyen Anayasal hüküm, yani bölümler arası aktarmanın ancak ayrı bir kanunla yapılabileceği hükmü de kaldırılmıştır. Bütçe hakkının kullanımı açısından oldukça hayati olan bu değişikliğe, Bütçenin Uygulanması" başlığında ayrıntılı olarak ayrıca değinilecektir. Yapılan önemli değişikliklerden, daha doğrusu eklemelerden bir tanesi de "Geçici 
Bütçe" uygulamasına ilk kez Anayasada yer verilmesi olmuştur ${ }^{5}$. Buna göre (Anayasa 161/4): "Bütçe kanununun süresinde yürürlüğe konulamaması halinde, geçici bütçe kanunu çıkarılır. Geçici bütçe kanununun da çıkarılamaması durumunda, yeni bütçe kanunu kabul edilinceye kadar bir önceki yılın bütçesi yeniden değerleme oranına göre artırılarak uygulanır".

CHS'ne geçilmesiyle birlikte Kalkınma Bakanlığı ve BÜMKO kapatılmış, Kalkınma Bakanlığının yetkileri Cumhurbaşkanlığı bünyesinde kurulan "Strateji ve Bütçe Başkanlığına" (SBB) devredilmiş, BÜMKO'nun "kontrol" yetkileri ise Muhasebat Genel Müdürlüğü bünyesine taşınarak, bu birimin adı "Muhasebat ve Mali Kontrol Genel Müdürlüğü" şeklinde değiştirilmiştir. Gelir Politikaları Genel Müdürlüğünün adı da Gelir Düzenlemeleri Genel Müdürlüğü olarak değiştirilmiştir. Hazine Müsteşarlığı ise Maliye Bakanlığı ile birleştirilerek Hazine Ve Maliye Bakanlığı (HMB) adını almıştır.

CHS'ne geçildikten sonra, Bakanlar Kurulu ilga edildiğinden, bundan böyle MYB Kanunu "Cumhurbaşkanlığı Teklifi" şeklinde TBMM'ne sunulabilmektedir (Cumhurbaşkanlığınca teklif edilebilen sadece iki kanun vardır: MYB Kanunu ve Kesinhesap Kanunu). Bu teklifler, SBB ve HMB tarafından koordinasyon içerisinde hazırlanmaktadır. Hazırlanan MYB Kanun Teklifi ve bir önceki yıl bütçesine ait Kesinhesap Kanun Teklifi Cumhurbaşkanınca son kez gözden geçirildikten sonra, mali yılbaşından 75 gün önce TBMM Başkanlığına gönderilmektedir. Bundan sonraki süreçler parlamenter sistemde olduğu gibidir. Ancak burada bazı idari değişiklikler söz konusu olmuştur: TBMM'de bundan böyle bir "iktidar partisinden" söz edilemeyeceği için, Bütçe Komisyonunda artık her parti TBMM'deki temsili nispetinde yer almaktadır. Ayrıca hükûmeti Cumhurbaşkanı kurduğu ve MYB Kanununu "teklif" ettiği için, gerek Komisyon gerekse Genel Kurul aşamasında, bütçe takdim konuşmasını, arzu etmesi halinde Cumhurbaşkanının kendisi (yahut Cumhurbaşkanı Yardımcısı veya Hazine Ve Maliye Bakanı) yapabilecektir. Ancak ilk uygulamalarda görüldüğü kadarıyla, bu görevin Hazine Ve Maliye Bakanınca yerine getirileceği anlaşılmaktadır.

\subsubsection{Yasama-Yürütme Ilişkisinde Kurulamayan Denge}

Bütçe hakkı bağlamında hükûmet sisteminin yapısına göre yürütme-yasama ilişkileri farklı durumlar arz edebilmektedir. Özellikle yasamanın bütçe üzerinde değişiklik yapması noktasında dört farklı uygulama ile karşılaşılmaktadır. Bunlardan en uç ve kısıtlayıcı ilk uygulama -çoğunlukla otoriter rejimlerde görülen- "kabul ve redde dayalı" bütçe hakkıdır. Bu uygulamaya göre bütçe teklifi üzerinde hiçbir değişiklik

\footnotetext{
${ }^{5}$ Gary W. Cox, 2012 yılında kaleme aldığı Ingilizce "The Power of the Purse and the Reversionary Budget" başlıklı analizinde, bütçe hakkının kullanımının zamanla yürütme lehine ve yasama aleyhine olacak şekilde, demokratik kazanımları aşındırdığını ve yürütmenin geçici bütçe ile harcama yapma eğilimi içinde olduğunu ifade eden, oldukça önemli değerlendirmelere yer vermiştir. Cox, 1875-2005 yılları arasındaki verilerden hareketle; dünya savaşları ve soğuk savaş sonrasında yeni devletler kurulurken, ülke anayasalarında, bütçesel açıdan, ciddi anlamda yürütme yararına (executive-favoring) hükümler olduğunu ve bunların sunulan geçici bütçe (reversionary budget) imkanlarıyla desteklendiğini ortaya koymuştur.
} 
yapamayan yasamanın önünde sadece bütçeyi ret veya kabul seçenekleri bulunmaktadır. Kısmen daha esnek olan ikinci uygulama ise sınırlı bütçe hakkıdır. Daha çok İngiltere gibi parlamenter hükümet sisteminin ve Fransa gibi yarı başkanlık sisteminin geçerli olduğu ülkelerde kullanılan sınırlı bütçe hakkına göre; bütçe üzerinde yasamanın değişiklik yapma hakkı sınırlı tutulmuştur. Nitekim yürütmenin mali politikası korunurken, yasamanın belirli bir limite kadar bütçedeki gelirleri azaltıp giderleri artırmasına veya sadece ödeneklerde kesinti yapmasına izin verilmektedir. Buna karşın yasamaya ödeneklerin yerini değiştirme, ödenek kalemlerini artırma veya yenilerini ihdas etme imkânı verilmemektedir. Buna karşın Almanya örneğinde, söz konusu değişiklikler aynı zamanda yürütmenin onayına diğer bir ifadeyle kabulüne bağlıdır. Ancak önemle belirtmek gerekir ki yasamanın bütçe üzerindeki bu sınırlı yetkisi, yasamanın bütçeye etki edemeyeceği anlamına gelmez. Bütçe hakkının sınıflandırılması noktasında bir diğer uygulama ise sınırlı bütçe hakkı ile sınırsız bütçe hakkı arasında değerlendirilebilecek dengeli bütçe hakkıdır. ABD'de "pay-as-you-go PAYGO" prensibi olarak da adlandırılan ve bütçenin tarafsızlığı ilkesinin gereği olan dengeli bütçe hakkına göre, yürütme tahminî bütçe açığını artıracak herhangi bir yasayı yürütemez. Diğer bir ifadeyle kamu gelirlerine ve zorunlu harcamalara yönelik yeni yasal düzenlemelerle tahmini bütçe açıkları artırılamaz. Bu prensibin uygulanabilmesi için hem iktisadi yapının güçlü olması hem de ekstra ve alternatif gelir kaynaklarının mevcut olması gerekmektedir. PAYGO prensibi sadece yürütme ile sınırlı olmayıp yasama için de geçerlidir. Eğer ki yasama belirli bir zorunlu harcamayı yapmaya yönelik gider artırıcı bir teklifte bulunacak ise -PAYGO prensibi gereğince- bu harcama için önceden kaynağı da bulmalıdır. Bu tip bir bütçe hakkında gözetilen ana amaç, bütçe dengesinin dışına çıkmadan yasamaya zorunlu kaynak ihtiyacı olan sektörlere kaynak tahsisi yapmak suretiyle- etki sahası açmaktır. Bütçe hakkı sınıflandırması bağlamında yasamaya en geniş hareket sahası sağlayan uygulama ise sınırsız bütçe hakkıdır. Başta $A B D$ olmak üzere başkanlık hükümet sisteminin geçerli olduğu ülkelerde uygulanan sınırsız bütçe hakkına göre; yasama yürütmenin onayına bağlı kalmaksızın, hem gelirler hem de giderler üzerinde sınırsız şekilde değişiklik yapma ve ödenekleri artırma ve yeniden tahsis etme hakkına sahiptir. Kontrol ve denge (check \& balance) yaklaşımı çerçevesinde, yasamanın yürütme üzerinde bu tip bir hakkı kullanması başkanlık vetosuyla dengelenmiştir. Diğer bir ifadeyle sert güçler ayrılığının geçerli olduğu başkanlık hükümet sisteminde, yasamanın bu tip değişiklik yapma hakkıyla yürütmenin işlerliğini engellememesi için başkana bütçe kanununu bir bütün halinde veya tek/birkaç madde bazında veto yetkisi tanınmıştır (Avci, 2015: 72-73).

Ancak Türkiye' de yürürlüğe giren CHS ile tam tersi bir yapıya gidilmiştir. Daha doğrusu, yönetim sistemi değişirken, Cumhurbaşkanının bütçe kanunu ve diğer kanunlar karşısındaki konumu korunmuştur. Eskiden olduğu gibi, Cumhurbaşkanı, diğer kanunları veto edebilecek, ancak bütçe kanununu geri gönderemeyecektir. Oysa tam tersi olması gerekirdi. Bütçe kanununu bundan böyle Cumhurbaşkanı "teklif" edeceğinden; TBMM'de muhalefet partilerinin çoğunlukta olması ve bu çoğunluğun bütçeyi, Cumhurbaşkanının tasarladığı maliye politikasının tam tersi yönde, değiştirmesi durumunda, Cumhurbaşkanı tamamen savunmasız kalmaktadır. Böyle bir 
tıkanıklık yaşanması durumunda, sistemin eldeki tek -ve pahalı- seçenek, parlamento ve kabinenin dağıtılması ve seçime gidilmesidir.

Burada yapılması gereken, mevcut durumun aksine, egemenlik kayıtsız şartsız milletin olduğuna ve milleti de TBMM temsil ettiğine göre, Cumhurbaşkanının, TBMM'nin geçirdiği diğer kanunlardaki veto yetkisinin kaldırılması, buna karşılık bütçe kanunu için ABD'dekine benzer bir veto mekanizmasının kurulmasıydı. Parlamentonun bütçe hakkı ile hükumetin maliye politikası arasında böylece optimum bir denge kurulabilecekti. Ancak getirilen yeni sistemde, Hükûmet ile Meclis arasında, bütçe konusunda ortaya çıkan fikir ayrılıkları sistemin tıkanmasına ve yeniden seçime gidilmesine neden olacaktır. Herhangi bir denge-fren mekanizması kurulmadığı gibi, milletin de böyle bir denge kurmasının önüne geçilmiştir. Devlet mekanizmasının kaosa sürüklenmeden veya tıkanmadan, sağlıklı bir şekilde çalışabilmesi için, millet, hem parlamentoya hem de hükumete aynı siyasal anlayışı taşımaya zorlanmış olmaktadır. Bunun ne kadar demokratik bir kurgu olduğu tartışmaya açıktır.

Kaldı ki, yeni sistemde Cumhurbaşkanı aynı zamanda bir siyasi partinin başkanı da olabilmektedir. (Şayet yetki verilmiş olsaydı) kendi siyasi çizgisini temsil eden bütçe kanunu üzerinde Meclis'in yapacağı değişikliklere karşı veto yetkisini kullanarak direnmesi anlaşılır olacaktı. Sadece diğer kanunlar için bu yetkinin şu anda devam ediyor olması, hiçbir demokratik değerle örtüşmemektedir. Bu sistemde, bir kanun milli egemenliğin tecelligâhı olan Meclis'ten geçtikten sonra, nihai onay için bir siyasi partinin başkanına (cumhurbaşkanına) gönderilmiş olmaktadır. Oysa demokratik bir sistemde, hiçbir siyasi aktör, milli egemenliğin üstünde değildir ve olmamalıdır. Dolayısıyla, yeni hükumet sistemi ve uygulaması, demokratik değerleri ve işleyişi ciddi manada sekteye uğratma potansiyeli taşımaktadır.

Esasen cumhurbaşkanının veto yetkisi, 1924 Anayasasından itibaren (yani Cumhuriyetin başından beri) tüm anayasalarımızda yer almıştır. Buna rağmen, ne akademik çalışmalarda, ne de politik mülahazalarda, bu yetki hiçbir şekilde tartışılmamış; egemenliğin kayıtsız şartsız sahibi olan Meclis'in çıkardığı kanunların, başka bir merciin onayına gitmesinin siyasi ve demokratik içerik ve sonuçları müzakere edilmemiştir. Yalnızca, 1924 Anayasası TBMM'de görüşülürken, Cumhurbaşkanına verilen bu onama/veto yetkisi önemli tartışmalara yol açmıştır. Özellikle Konya Mebusu Refik Bey, bu veto yetkisine şiddetle karşı çıkmış ve ilgili Anayasa maddesinden (madde 35) çıkarılmasını talep etmiştir. Meclis tutanaklarından ${ }^{6}$ Refik Bey'e (Koraltan) kulak verecek olursak:

"Arkadaşlar! icraîi ve teşriî [yasama] salâhiyet bizdedir. Bir kaç defa bu kürsüden arz ettiğim gibi icraî salâhiyet bizdedir, demekte manayı şerif nedir? Bunu anlamıyorum. Nedir arkadaşlar? Yine maddeye taalluku [ilgisi] vardır. Bendeniz diyorum ki eğer prensibimiz ve müdafaa ettiğimiz esas elimize verilen şu Teşkilâtı Esasiye Kanunu projesi, vahdeti kuvanın [kuvvetler birliği] ifade ettiği mana ve mefhumdan ibaret ise bir hakkınızı hiç bir tarafa veremezsiniz ve bu veto hakkı da (veto değil sesleri) veto, veto değil. Efendim! REISICUMHUR Meclis tarafından kabul olunan kanunların isdar [onay] ve

\footnotetext{
${ }^{6}$ TBMM Zabıt Ceridesi (Yirmi Dördüncü İçtima), Devre: II, Cilt:8, İçtima Senesi: II, 30.3.1340 (30.3.1924), https://www.tbmm.gov.tr/tutanaklar/TUTANAK/TBMM/d02/c008/tbmm02008024.pdf, [19.09.2018].
} 
Akbey, F. (2020). “Cumhurbaşkanlığı Hükûmet Sisteminde Bütçe Hakkı ve Kanunu”, International Journal of Public Finance, 5(1), 1-26.

ilânını muvafık görmediği takdirde Mazbata Muharriri Beyefendinin buyurduğu veçhile [usülde] on gün zarfında tekrar müzakere edilmek için esbabı mucibesiyle [gerekçesiyle] birlikte bir ay zarfında meclise iade eder. (On gün sesleri) on gün olsun efendim, iade hakkı veriyorsunuz, kendi tarafından yapılan bir kanunu kendi azasından [üyesinden] olan bir zat yine size iade ediyor. Bu ne oluyor?

Ne olursa olsun, reddetsin, iade etsin, Heyeti Celilenizin kabulüne iktiran eden [ulaşan] ve kanuniyet iktisap eden bir kanunu kendi azanız meyanında bulunan bir zat size iade ediyor, tabiî o iade bazı sebeplere istinat ediyor. Ya bu kanunu şu itibarla noksandır diyecek veya şu itibarla memleketin menafiine muvafık olmadığını söyleyecek, bu esasların varit olacağına [muhtemel olacağına] kani olanlardanım, fakat takip ettiğimiz prensip itibariyle doğru bulmuyorum. Ya tefriki kuvayı [kuvvetler ayrılığını] kabul edeceğiz yahut hiçbir suretle hiçbir hakkınızı kimseye vermiyeceksiniz. Bu itibarla bendeniz Teşkilâtı Esasiye Kanunu halitası [karışımı] olan bu kanun reye [oya] vazedildiği [sunulduğu] zaman reyimi kırmızı vereceğim. Çünkü anlamadım, anlamakta mazurum, bunun tatbikatına imkân yoktur. Döneceksiniz, ricat edeceksiniz, yol yakın iken dönünüz, inkılâba [darbeye] meydan vermeyiniz".

Paralel olarak Sivas mebusu Halis Turgut Bey, görüşülmekte olan Anayasanın 35 inci maddesinin "Reisicumhur Meclis tarafından kabul olunan kanunları derhal neşir ve ilân eder" şeklinde değiştirilmesini ve kalan fıkraların kaldırılmasını teklif eder, ancak bu teklif Meclis tarafından oylanıp reddedilir.

Bütçe kanunlarının (ve görüşülmekte olan Anayasa metninin) cumhurbaşkanının veto yetkisinden istisna tutulmasını öneren ve Meclis'e kabul ettiren ise Konya mebusu Musa Kâzım Efendi'dir (Onar). Musa Kâzım Efendi, bu teklifinin gerekçesini ise şöyle açıklamıştır:

"Reis Bey!

Iki kelime söyliyeceğim. Efendim! Encümenin gösterdiği esbabı mucibe herhangi bir kanunun kabulünde ve Mecliste müzakeresinde vukuumelhuz [zararlı] bir zühulün [gecikmenin], yahut acil bir surette kabul edildiğinden dolayı vuku bulan bir hatanın tashihidir. Bütçe kanunları ve Teşkilâtı Esasiye Kanunu gibi kanunları bu ihtimalâttan azadedir. Bütçe kanunlarının iadesi ve tekrarı gibi şeyler, memleket için menfaatli değildir ve bunlarda hata varit [ihtimal dahilinde] değildir. Ezcümle, encümenin zaten beyan ettiği esbabı mucibeye göre bunların iadesi muvafık [yerinde] değildir. Bendeniz bunların istisnasını teklif ediyorum".

Bütçe hakkını cansiperane savunan bu üç vekilden Refik Bey (Koraltan / 18891974) 1946 yılında kurulan Demokrat Partinin dört kurucusundan biri olmuş, hatta 22 Mayıs 1950 ile 27 Mayıs 1960 arası dönemde TBMM Başkanlığı yapmıştır. 27 Mayıs darbesinden sonra yargılanarak hapis yatmış, ancak bir süre sonra aftan yararlanarak çıkmış ve bir daha aktif siyasete dönmemiştir. Halis Turgut Bey (1886-1926), Terakkiperver Cumhuriyet Fırkasının (TCF) kurucuları arasında yer almış, ancak Haziran 1926 'da İzmir'de Atatürk'e suikast girişiminin açığa çıkması üzerine, bu girişim ile TCF arasında irtibat olduğu gerekçesiyle Fırka kapatılmıştır. Sonrasında kurulan i̇stiklal Mahkemelerinde yargılananlardan biri olan Halis Turgut Bey Temmuz 1926'da idam edilmiştir. İronik olarak, o süreçte yargılanıp idam edilenlerden biri de eski Maliye Nazırı Cavid Bey'dir. Musa Kazım Efendi (Onar / 1881-1930) ise güçlü kişiliği ve etkileyici hitabeti ile Meclis'te oldukça itibarlı şahsiyetlerden biri olarak ilk dört dönem 
kesintisiz şekilde vekillik yapmıştır. Ancak 1929 yılında rahatsızlanmış ve tedavi için Viyana'ya gönderilmiştir. 1930 senesinde tam Türkiye'ye geri döneceği sırada, ailesinden uzakta Viyana'da vefat etmiştir. Görüldüğü gibi tarihsel bir gerçeklik olarak bütçe hakkını savunanları pek de parlak bir gelecek beklememektedir.

\subsection{Bütçenin Uygulanmasında Belirsizlikler ve Potansiyel Riskler}

Hükûmet sisteminin değişmesi, doğal olarak bütçenin uygulanma süreçleri açısından da değişiklikler getirmiştir. Bunlardan ilki "harcama yetkilisine" ilişkindir. Parlamenter sistemde, 5018 sayılı Kanunun 31 inci maddesinde harcama yetkilisi "bütçeyle ödenek tahsis edilen her bir harcama biriminin en üst yöneticisi" olarak tanımlanmıştı. Aynı Kanunun 11 inci maddesine göre "Bakanlıklarda müsteşar, diğer kamu idarelerinde en üst yönetici, il özel idarelerinde vali ve belediyelerde belediye başkanı" en üst yönetici olduğundan, bakanlıklarda Müsteşar doğal olarak aynı zamanda harcama yetkilisi sıfatını da taşımaktaydı. Lâkin CHS'ne geçiş sürecinde 2016 ve 2018 yıllarında yapılan değişikliklerle, 5018 sayılı Kanunun 11 inci maddesinin ilk fıkrası şu şekilde değiştirilmiştir: "Bakanlıklarda ve diğer kamu idarelerinde en üst yönetici, il özel idarelerinde vali ve belediyelerde belediye başkanı üst yöneticidir. (Mülga ikinci cümle: 3/10/2016-KHK-676/69 md.; Aynen kabul: 1/2/2018-7070/55 md.)(...) (Ek cümle: 2/7/2018-KHK-703/213 md.). Bakanlıklarda en üst yönetici Cumhurbaşkanı tarafından belirlenir". Sonrasında yayımlanan 09 Ağustos 2018 tarih ve 2018/5 sayılı Cumhurbaşkanlığı Genelgesine göre ise "Bakanlar kendilerine doğrudan bağı hizmet birimleri bakımından, bakan yardımcıları ise kendilerine bağlı hizmet birimleri bakımından bakanlık en üst yöneticisi sayılırlar".

Görüldüğü gibi, harcamacı kurumların bakanlıklar ayağında, üst yöneticiyi belirleme yetkisi Cumhurbaşkanındadır. Dolayısıyla, Cumhurbaşkanı bu yetkiye dayanarak, Bakan veya yardımcılarından birini, yahut her yardımcısını ayrı ayrı üst yönetici olarak atayabilmektedir. Bakanlıklarda Müsteşarlık makamının kaldırılması, bu şekilde esnek, diğer yandan da belirsiz bir süreci beraberinde getirmiştir.

Nitekim 5018 sayılı Kanunun mevcut halinde bu konuda bir yasal boşluk bulunmaktadır. Mezkur Kanunun 11 inci maddesinin ikinci fıkrasında "[ü]st yöneticiler, idarelerinin stratejik planlarının ve bütçelerinin kalkınma planına, yıllık programlara, kurumun stratejik plan ve performans hedefleri ile hizmet gereklerine uygun olarak hazırlanması ve uygulanmasından, sorumlulukları altındaki kaynakların etkili, ekonomik ve verimli şekilde elde edilmesi ve kullanımını sağlamaktan, kayıp ve kötüye kullanımının önlenmesinden, malî yönetim ve kontrol sisteminin işleyişinin gözetilmesi, izlenmesi ve kanunlar ile Cumhurbaşkanlığı kararnamelerinde belirtilen görev ve sorumlulukların yerine getirilmesinden Bakana; mahallî idarelerde ise meclislerine karşı sorumludurlar" denmektedir. Görüldüğü gibi, üst yöneticiler, Bakana karşı sorumludurlar; ancak gerek "Bakanlar" başlıklı 10 uncu maddede, gerekse "Üst Yöneticiler" başlıklı 11 inci maddede, üst yöneticilerin idari/mali tasarruflarının Bakanın sorumluluğunu ortadan kaldırmayacağına yönelik bir hüküm söz konusu değildir. Her ne kadar aynı Kanunun 31 inci maddesinin 5 inci fıkrasının son cümlesinde "[h]arcama 
yetkisinin devredilmesi, yetkiyi devredenin idarî sorumluluğunu ortadan kaldırmaz" hükmü yer alsa da, burada durum farklıdır. Çünkü burada yetki devri değil, yetkinin Cumhurbaşkanı Genelgesi ile makamlar arasında el değiştirmesi söz konusu olacaktır. Bu mesele, dolaylı olarak TBMM'nin bütçe hakkının kullanımını da olumsuz etkileyecektir. TBMM adına bütçe hakkı çerçevesinde denetim yapan Sayıştay, her an muhatapsız bir usulsüzlük tespiti ile karşı karşıya kalabilecektir. Sorunun giderilmesi için 5018 sayılı Kanunun 10 uncu, 11 inci veya 31 inci maddesine, harcama yetkilisi hangi makam olursa olsun, Bakanların sorumluluğunu belirten bir hükmün eklenmesi, TBMM'nin bütçe hakkına istinaden Sayıştay'ca gerçekleştirilecek olan denetimlerin kâmilen neticelendirilebilmesi açısından yerinde olacaktır.

Bütçenin uygulanması konusunda, CHS ile getirilen en kritik değişiklik ise MYB içi, bütçeler ve bölümler arası ödenek aktarmalarına ilişkindir. CHS öncesinde, Anayasanın "Bütçede Değişiklik Yapma Esasları" başlıklı 163 üncü maddesi ile 5018 sayılı Kanunun "Ödenek Aktarmaları" başlıklı 21 inci maddesinde bölümler arası aktarmaların ancak kanunla yapılabileceği hüküm altına alınmıştı (5018 sayılı Kanunun mezkur maddesinde, bunun istisnası olarak, harcamacı kurumların kendi bütçeleri içinde aktarmaya intiyaç duyulan tertiplere, yılı bütçe kanununda farklı bir oran belirlenmedikçe, aktarma yapılacak tertipteki ödeneğin yüzde 5'ine kadar bölümler arası aktarma yapabileceği hükmü yer almaktaydı). Bölümler arası aktarmanın bu şekilde sınırlandırıması, esasen bütçe hakkının bir sigortasıydı. Çünkü bu kısıtlar, iktidarın, parlamento tarafından belirlenmiş bütçe kompozisyonunu, yıl içinde istediği gibi değiştirmesini, diğer bir ifadeyle bütçe hakkını by-pass etmesini, bütçe hakkını iğdiş ederek fiilen ortadan kaldırmasını engelleyen Anayasal/yasal bir güvence sunmaktaydı.

Bu güvenceyi esnetmeye yönelik ilk adım 24/11/2016 tarihli resmi gazetede yayımlanan 6761 sayılı "Kamu Malî Yönetimi ve Kontrol Kanunu ile Bazı Kanunlarda Değişiklik Yapılması Hakkında Kanunun" 1 inci maddesi ile atılmıştır. 5018 sayılı Kanunun 21 inci maddesi değiştirilmiş, sonrasında; 2/7/2018 tarihli ve 703 sayılı Kanun Hükmünde Kararnamenin 213 üncü maddesiyle de (e) bendinde yer alan "Maliye Bakanlı̆̆ınca" ibaresi "Cumhurbaşkanlığı tarafından" şeklinde değiştirilmiş ve (g) bendinde yer alan "Bakanlar Kurulu kararıyla" ibaresi madde metninden çıkarılmıştır.

Buna göre, Anayasa ve 5018 sayılı Kanunun 21 inci maddesi birlikte düşünüldüğünde, daha önce, yüzde beşlik istisna haricinde, bölümler arası harcama sadece kanunla, yeni TBMM'nin bütçe hakkı çerçevesinde yapılırken, bundan böyle;

- 5018/21-1 gereği: Kanunla,

- Genel Bütçe ödenekler toplamının \%10'una kadar MYB Kanununda yetkilendirme ile,

- Aktarılacak tertibin \%20'sine kadar harcamacı kurum kararı ile,

- Yüzde 20'yi aşan aktarmalar ise kurum bütçesinin \%20'sine kadar Cumhurbaşkanınca gerçekleştirilebilmektedir.

En önemli konu da, Anayasanın "Bütçede Değişiklik Yapma Esasları" başlıklı 163 üncü maddesinin kaldırılmasıdır. Yani 5018 sayılı Kanunun ödenek aktarmaları için yeni kanun çıkarılmasını zorunlu kılan 21 inci maddesinin 1 inci fıkrası değiştirildiğinde, ilgili 
maddede yapılacak diğer değişikliklerle hükûmet, MYB içinde sınırsız aktarma yetkisi elde edilebilecektir. Bu durum TBMM'nin bütçe hakkının zedelenmesinden başka bir şey değildir. Elbette ki hükûmetin maliye politikası hakkının da gözetilmesi gerekecektir. Ancak TBMM'nin bütçe kanununu "bölümler halinde onama" usulüyle tecessüm eden bütçe hakkının, bu şekilde alenen iğdiş edilmesi (TBMM'nce ayrı ayrı onanan -yani birer Meclis Kararı haline gelen- bölümler arasında hükûmetin idari kararlarla aktarma yapma yetkisinin sürekli olarak genişletilmesi) bunun bedeli olmamalıdır. Hülasa, Meclis Kararlarının idari kararlarla aşılabilmesi sürecine Anayasal bir sınır konması elzemdir.

Bütçenin uygulanması ile ilgili önemli hususlardan biri de kamu gelirleri ile ilgilidir. CHS'ne geçiş için Anayasa referandumu neticesinde getirilen değişikliklerden biri de, önceki sistemde Bakanlar Kuruluna tanınan "vergi, harç ve benzeri mali yükümlülüklerin muaflık, istisnalar ve indirimleriyle oranlarına ilişkin hükümlerinde kanunun belirttiği yukarı ve aşağı sınırlar içerisinde değişiklik yapma yetkisinin", Anayasa'nın 73/4 maddesinde yapılan değişiklikle Cumhurbaşkanına verilmesidir. Örneğin, bundan böyle kanuni oranı yüzde 10 olan KDV, Cumhurbaşkanı Kararnamesi ile dört katına kadar artırılıp yüzde 1'e kadar düşürülebilecektir (önceki sistemde bu yetki Bakanlar Kuruluna aitti). Esasen bir verginin oranını bir kat ve daha fazla artırmak, eski sistemde bile yeni vergi ihdası anlamına gelmekteydi ve bu yetki, Meclis'i devre dışı bıraktığı için önemli tartışmalara konu olmaktaydı. Ancak yine de, vergi oranında değişiklik kararı bir "heyet" (Bakanlar Kurulu) tarafından verilmekteydi; yani istişare ve müzakere süreçlerinden geçerek hayat bulmaktaydı. Oysa yeni sistemde bu yetki, tek bir kişinin iradesine terk edilmiştir. Dolayısıyla, mükelleflerin mali durumunu önemli ölçüde etkileyecek bu kadar önemli kararların, iyi-kötü bir müzakere ortamından değil de, tek kişinin takdirinden sadır olması, her halükârda demokrasi ile uyumlu bir görünüm sergilemeyecektir. Bu açıdan Anayasada belirtilen "yukarı ve aşağı sınırların" daraltılması, aynı kalacak olması halinde de bu sınırlar dahilinde yapılacak vergi oranı düzenlemelerinin TBMM'nin onayına bağlanması, temsili demokrasi bağlamında, daha yerinde olacaktır.

\subsection{Hesap Yargılaması ve Bütçe Denetiminde "Siyasal" Risk}

16 Nisan 2017 referandumuyla yapılan Anayasa değişikliği ile, bütçe denetimine ilişkin olarak, gerek idari, gerekse Kesinhesap Kanunu ile ilgili olarak, Meclis'in bütçe hakkına etki eden değişiklikler yapılmıştır. Görünüşte usulen ve basit görünen bu değişiklikler, ayrıntılı olarak tahlil edildiğinde bütçe hakkı kapsamında, yasama-yürütme ilişiklerine önemli etkilerde bulunabilecek düzenlemeler oldukları görülmektedir.

Yapılan değişiklikle, Anayasanın Cumhurbaşkanının görev ve yetkilerini düzenleyen 104 üncü maddesine iki önemli fıkra eklenmiştir: Bunlardan ilki, 9 uncu fıkra şu şekildedir: "Üst kademe kamu yöneticilerini atar, görevlerine son verir ve bunların atanmalarına ilişkin usul ve esasları Cumhurbaşkanlığı kararnamesiyle düzenler". Diğeri, $17 \mathrm{nci}$ fıkrada ise "Cumhurbaşkanı, yürütme yetkisine ilişkin konularda Cumhurbaşkanlığı kararnamesi çıkarabilir" hükmü yer almıştır. 
Yukarıdaki iki fıkra hükmüne istinaden, Cumhurbaşkanlığınca 10/07/2018 tarih ve 30474 sayılı Resmi Gazetede yayımlanan 3 Sayılı Cumhurbaşkanlığı Kararnamesinin 4 üncü maddesi ile, Kararnameye ekli I sayılı cetvelde yer alan üst düzey yöneticilerin Cumhurbaşkanınca atanacağı ve görev sürelerinin Cumhurbaşkanının görev süresini geçemeyeceği hüküm altına alınmıştır. Bütçe denetimi konusunda, mezkur I sayılı cetvelde yer alan dört adet kadro dikkat çekmektedir: Bunlar Devlet Denetleme Kurulu Başkan ve Üyeleri, İç Denetim Koordinasyon Kurulu Üyeleri, Vergi Denetim Kurulu Başkanı ve en önemlisi Sayıştay Başsavcısıdır.

İlk üç kadroda yer alanların Cumhurbaşkanı ile göreve gelip gitmeleri, hükûmetin (gelir ve giderler itibariyle) maliye politikası öncelikleri, hükûmet içi mali denetim hassasiyetleri ve yönetim bütünlüğü dikkate alındığında, anlaşılabilirdir. Ancak mali açıdan, TBMM'nin bütçe hakkı çerçevesinde, Cumhurbaşkanlığını da denetleyen Sayıştay'ın (dört yıllığına Cumhurbaşkanınca atanan) Başsavcısının görev süresinin Cumhurbaşkanına bağlanması, yani görevden alınmasının veya yeniden atanmasının Cumhurbaşkanının takdirine bırakılması, Cumhurbaşkanının hükûmet ettiği yürütmenin mali işlemlerinin hesap yargılamasında önemli bir konumu olan Başsavcının, yapacağı ve neticelendireceği her türlü soruşturmayı sorgulanır hale getirme potansiyeli taşımaktadır. Sayıştay TBMM adına, yani millet adına mali denetim yapmakta, kamu zararı veya usulsüzlük tespit ettiğinde ise hesap yargılaması yapmaktadır. Anayasa Mahkemesinin çeşitli kararlarına da yansıdığı gibi (örneğin 2/04/2013 tarih ve 28606 sayılı RG'de yayımlanan ve E.: 2012/102 K.: 2012/207 sayılı Kararı; 6.03.2014 tarihli ve 28933 sayılı RG'de yayımlanan E.:2011/21 K.:2013/36 sayılı Kararı) her ne kadar Anayasada yüksek mahkemeler arasında sayılmış olmasa da, denetimsel konumunun yanı sıra, Sayıştay esasen bir "yargı merciidir". Böyle bir merciin Başsavcısının, aynı zamanda bir siyasi partinin genel başkanı da olabilen Cumhurbaşkanınca atanması, yargının siyasallaşmasına yol açabileceği gibi, Anayasanın Hakimlik ve Savcılık Teminatını düzenleyen 139 uncu maddesinde yer alan "[h]âkimler ve savcılar azlolunamaz, kendileri istemedikçe Anayasada gösterilen yaştan önce emekliye ayrılamaz; bir mahkemenin veya kadronun kaldırılması sebebiyle de olsa, aylık, ödenek ve diğer özlük haklarından yoksun kılınamaz" hükmüne de aykırılık teşkil edecektir. Kaldı ki TBMM adına denetim yapan bir kurumun en önemli memurlarından birinin, TBMM dışından atanması da ayrıca sorgulanmaya değerdir.

CHS ile getirilen bir diğer değişiklik ise Kesinhesap Kanununa (KHES) ilişkindir. Buna göre (AY 161/9) "kesinhesap kanunu teklifi, ilgili olduğu malî yılın sonundan başlayarak en geç altı ay sonra Cumhurbaşkanı tarafından Türkiye Büyük Millet Meclisine sunulur". Diğer bir deyişle, bütçe kanununda olduğu gibi, kesinhesap kanunu da yalnızca Cumhurbaşkanınca "teklif” edilecek ve Meclis'ten geçtikten sonra tekrar Cumhurbaşkanının onayına gidecektir. Yani Cumhurbaşkanı kendi teklifini onaylayacaktır.

Meclis'ten geçen Cumhurbaşkanı teklifinin yeniden Cumhurbaşkanının onayına gitmesinin, kamu maliyesinin en temel ilkelerinden olan "görevlerin ayrılığı ilkesi" açısından bir tezat oluşturduğu aşikârdır. Bu ilkenin yansımalarından olan 5018 sayılı Kanunun 60/4 maddesine göre "[h]arcama yetkilisi ile muhasebe yetkilisi görevi aynı 
kişide birleşemez. Malî hizmetler biriminde ön malî kontrol görevini yürütenler malî işlem sürecinde görev alamazlar"; benzer şekilde, iç Kontrol ve Ön Mali Kontrole Iliş̧kin Usul ve Esaslar'ın 15 inci maddesine göre: "[h]arcama yetkilisi ile muhasebe yetkilisi aynı kişi olamaz. Ön mali kontrol görevi olanlar; taahhüt, sözleşme, şartname evrakının hazırlanmasında görevlendirilemez. Bunlar ihale ve/veya muayene kabul komisyonlarına başkan ve üye olamazlar". Özetle, kamu kaynağının tahsiline ve sarfına karar verenler, bu kararların denetlendiği süreçlerde görev alamazlar. Oysa burada, kamusal kaynakların ne şekilde tahsil edilip sarf edileceğine karar veren Cumhurbaşkanı, aynı zamanda, bu kararların denetim sonucunun yer aldığı KHES'i denetlemektedir (son onayı vermektedir).

Esasen kesinhesap kanunu belki de hiçbir hukuki sonuç doğurmayan tek kanun türüdür. Gerek Anayasada gerekse diğer mer'i mevzuatta, kesinhesap kanununun parlamentoda reddedilmesi halinde hangi hukuki neticenin ortaya çıkacağına dair bir hüküm yoktur. Kesinhesap kanunu bir anlamda kamusal kaynakları kullanan iktidarın milletle ibralaşmasıdır. Ancak bu ibralaşma gerçekleşmediğinde, yani kesinhesap kanunu parlamentoda reddedildiğinde, bunun yasal bir yaptırımı da söz konusu olmayacaktır. Bu kanun esasen bir denetim raporundan öte bir anlam taşımamaktadır. $\mathrm{Bu}$ bağlamda, kesinhesap kanununun (şayet yolsuzluk iddiası söz konusu değilse) hukuki değil siyasi netice doğuracağını ifade etmek yanlış olmayacaktır. Ancak yine de gerek bir denetim raporu mahiyeti taşıması, gerekse en azından ismen TBMM'den geçen bir Kanun olması hasebiyle, denetlenen mali süreçlerin sorumlusu olan bir kişinin nihai onayına gitmesi, demokratik açıdan pek de müspet bir görüntü vermemektedir.

\section{Sonuç Yerine: Sistemin Revizyonuna Yönelik Öneriler}

Anayasal ve yasal altyapısıyla beraber etkin bir bütçe sistemi, bir yandan parlamentonun bütçe hakkını muhafaza edecek şekilde kesin kurallar ve sınırlar koyarken, diğer yandan yürütme erkinin maliye politikası hakkını dinamik biçimde icra etmesini sağlayacak esnekliği de sağlayabilmelidir. Burada bütçe hakkından kasıt; MYB Kanununun şüpheye yer bırakmayacak biçimde nihai olarak Parlamento onayından geçmesi; geçtikten sonra bütçeler (genel, özel, DDK bütçeleri) ve bölümler arası aktarmaların, Anayasa ve yasalarca belirlenmiş ve bütçe hakkını anlamsız kılacak şekilde geniş tutulmamış sınırlar dahilinde yapılabilmesi; ve ayrıca bütçe uygulandıktan sonra, Parlamento denetiminin sağlıklı ve objektif olarak yapılabilmesidir. Hükûmetin maliye politikası hakkı ise, oldukça dinamik ve değişken iktisadi/mali koşullar karşısında, icranın, bütçe ile ilgili çok katı Anayasal ve yasal usul ve kurallara takılmadan; harcama, gelir ve borçlanma politikası uygulayabilmesini ifade etmektedir. Özetle bütçe hakkı, maliye politikası oluşturan ve uygulayanların ayağına pranga olacak biçimde aşırı katı ve bürokratik (yahut jüristokratik) bir yapıya bürünmemeli; maliye politikası hakkı, bu çok katı olmayan Anayasal ve yasal sınırlar dahilinde kullanılmalı, bu yapılırken de, bütçe hakkını iğdiş edecek biçimde, bahsedilen sınırlar zorlanmamalıdır.

Türkiye'de yürürlüğe giren CHS'nde ise, bu şekilde etkin bir bütçe sistem ve sürecinin mevcut olduğunu iddia etmek maalesef güçtür. Yürütmenin başı olarak 
Cumhurbaşkanlığı, bütçe hakkını (görünürde olsa bile) anlamsız kılacak şekilde; kendi teklif ettiği MYB ve KHES'e nihai onayı yine kendisi vermekte; (Bakanlar Kurulu gibi) bir istişare ve müzakere mekanizmasına ihtiyaç duymadan, vergi, harç ve benzeri mali yükümlülüklerin nispetlerini, yasalarda belirtilmiş aşağı ve yukarı sınırlar dahilinde değiştirebilmekte; Cumhurbaşkanlığını da mali açıdan denetleyen Sayıştay'ın Başsavcısını atayabilmekte ve tekrar atanması konusunda takdir yetkisine sahip olmakta; ve nihayet bütçeler ve bölümler arası aktarma yapma konusunda hiçbir Anayasal sınırlamaya tabi olmamaktadır (yani 5018 sayılı Kanunun 21 inci maddesinde yapılacak bir değişiklikle, Cumhurbaşkanlığı sınırsız aktarma yetkisine sahip olabilecektir).

Parlamento ise, yürütmenin maliye politikası hakkını zedeleyecek şekilde; Komisyonda, gider artırma ve gelir azaltma dahil, bütçe üzerinde her türlü değişiklik yapabilmekte; Cumhurbaşkanının, kendi maliye politikasını akamete uğratacak bu değişiklikleri veto etme yetkisi de olmadığından, Parlamentonun tasarrufu yüzünden çarpık hale getirilen maliye politikasının müsebbibi Parlamento olmakla birlikte, siyasi bedelini Cumhurbaşkanına ödetebilmektedir. Özetle mevcut sistem ne Parlamentonun bütçe hakkını, ne de yürütmenin başı olarak Cumhurbaşkanının maliye politikası hakkını koruyabilmektedir. Bütçe hakkı ile maliye politikası hakkı arasında sağlıklı bir dengenin kurulabilmesi için, aşağıdaki tedbirlerin alınması tarafımızca önerilmektedir:

- Öncelikle Resmi Gazete, kanunları yapmakla görevli ve egemenliğin kayıtsız şartsız tecelligâhı olan TBMM'ye bağlanmalı, her türlü mevzuat milletin temsil makamı tarafından gözden geçirilerek yayımlanmalıdır.

- Egemenlik kayıtsız şartsız milletin olduğundan, TBMM'den geçen mevzuatın (MYB Kanunu ve KHES dahil), Cumhurbaşkanının (mevcut sistemde aynı zamanda bir siyasi partinin genel başkanı da olabilmektedir) onayına gitmesi uygulamasına son verilmelidir.

- Cumhurbaşkanının maliye politikası hakkının korunabilmesi için; MYB Kanunu TBMM'de görüşülürken; ya (Genel Kurulda olduğu gibi) Komisyon aşamasında da gider artırıcı ve/veya gelir azaltıcı öneride bulunma yasağı getirilmeli, yahut Cumhurbaşkanına gider artırıcı ve/veya gelir azaltıcı önerileri veto etme yetkisi tanınmalıdır.

- Esasen yeni hükumet sisteminde Cumhurbaşkanı da doğrudan milletin seçimiyle işbaşına geçtiğinden, Meclis ile aynı bağlamda olmasa da, milletin temsilcisi konumundadır ve yetkilerini milletten ve Anayasadan almaktadır. Yeni sistemde millet TBMM'ni yasa yapmak, Cumhurbaşkanını ise yasaları uygulamak, konumuz bağlamında ise maliye politikası oluşturup hayata geçirmekle görevlendirmektedir. Dolayısıyla milletten aldığı yetkiye dayanarak maliye politikası geliştiren ve uygulayan Cumhurbaşkanının bu yetkisine, bütçe dengesini bozacak şekilde aşırı Meclis müdahalesi, bir bakıma "fonksiyon gaspı" anlamı taşıyabilecektir. İşte bunun engellenmesi için, Cumhurbaşkanına maliye politikasına halel getirecek Meclis müdahalelerini veto etme yetkisinin tanınması elzemdir.

- Sayıştay Başsavcısının Cumhurbaşkanınca atanması ve görev süresinin Cumhurbaşkanı ile birlikte sona ermesi uygulamasına son verilmeli; TBMM adına denetim yapan Sayıştay'ın Başsavcısı, yine TBMM tarafından atanmalı; ayrıca görev süresi ve diğer özlük hakları, Anayasanın 139 uncu maddesinde yer alan yer alan "hakimlik ve savcılık teminatı çerçevesinde yeniden düzenlenmelidir. 
- Anayasanın 73 üncü maddesine eklenecek bir hükümle; vergi, harç ve benzeri yükümlülükleri düzenleyen kanunlarda, Cumhurbaşkanının takdirine bırakılan "yukarı ve aşağı sınırlara" bir sınır getirilmelidir. Yukarıda da bahsedildiği gibi, Cumhurbaşkanı KDV oranlarını, kanuni oranın dört katına kadar artırabilmekte ve yüzde bire kadar düşürebilmektedir. Bu oldukça geniş bir yetkidir ve verginin kanuniliği ilkesi ile bütçe hakkını adeta anlamsız kılmaktadır. Örneğin, vergi, harç ve benzeri yükümlülüklerin oranlarının yukarı sınırının "iki kat" ile sınırlandırılması, aynı zamanda mükelleflerin vergi sistemine olan güveninin artmasına ve ayrıca vergiye gönüllü uyuma olumlu etkide bulunabilecektir.

- Mevcut sistemde bir "ekonomi bakanlığı" veya "ekonomiden sorumlu bakanlık" yoktur. Yani seksen milyonluk nüfusa sahip bir ekonominin dümeninde kimin olduğu belli değildir. Devlet maliyesinin sorumluluğu ise HMB ile SBB arasında pay edilmiştir. Koordinasyon eksikliği söz konusu olduğunda, özellikle ortak üretilen metinlerde (MYB ve KHES gibi) dil-üslup uyuşmazlıkları, hatta veri uyuşmazlıkları görülebilecektir. Bu yüzden, bu birimler birleştirilmeli ve "Ekonomi ve Maliye Bakanlığı" ihdas edilmelidir. Dolayısıyla, ekonomik planlama ile, devlet maliyesi ve nakit yönetimi arasında bütünlügün sağlanması daha kolay olacaktır. Hatta Ticaret ile Sanayi ve Teknoloji Bakanlıkları da bu bünyeye eklenmelidir. Böylece, maliye politikasını da içeren bütüncül bir ekonomi politikası oluşturmak ve etkin bir şekilde uygulamak kolaylaşacaktır.

Elbette alınacak, Anayasal, yasal ve idari tedbirler bunlarla sınırlı değildir; ancak çalışmanın odağı ve sınırları açısından ilk etapta yukarıda sayılan tedbirlerin alınması yerinde olacaktır. Böylelikle; Parlamentonun bütçe hakkı ile yürütme organının maliye politikası hakkı arasında etkin bir denge-fren mekanizması kurulabilecek, bürokrasi/kırtasiyecilik ve koordinasyon sorunları belli oranda giderilecek, en önemlisi de ekonomi politikası bütüncül bir yaklaşım ve yapıya kavuşacaktır. Yasama ile yürütme arasında yetki ve sorumluluk paylaşımı berraklaşacağından, temsili demokrasi açısından da olumlu katkılar sağlayacaktır. Tabi ki, asıl önemli olan, sistemde reforma yahut revizyona gitmek değil, yapılan değişikliklerin, ruhuna uygun olarak uygulanmasıdır. Genelde devlette, özelde ise ekonomi/maliye yönetiminde ehliyet ve liyakate dayalı, dinamik kadroların oluşturulması da bu açıdan elzemdir. En kaliteli kumaşın, kötü terzinin elinde kolaylıkla çaputa dönüşebileceği unutulmamalıdır.

\section{Kaynakça}

Akbey, F. (2014). "Kamu Bütçesinde Yapı-Araç Uyuşmazlığı: Kuramsal Analiz”, Yönetim ve Ekonomi Araştırmaları Dergisi, 24, 18-40.

Avci, M. A. (2015). "Yasamanın Birincil Güçlü Silahı Bütçe Hakkı: Teorik Bir Yaklaşım”, Atatürk Üniversitesi Sosyal Bilimler Enstitüsü Dergisi, 19(1), 69-80.

B., F. (1930). Bütçe ve Muhasebe-i Umumiye Izahları, Damga Matbaası, Ankara. 
Bacon, R. (2008). "Parlamentonun Denetim ve İzleme Fonksiyonları: İngiltere Deneyimi", Bütçe Sürecinde Parlamentonun Değişen Rolü (Uluslararası) Sempozyumu: Bildiri ve Makaleler Kitabı, (Der.) Bütçe Müdürlüğü, TBMM Plan ve Bütçe Komisyonu, Afyonkarahisar, 229-246.

Batırel, Ö. F. (1987). Kamu Bütçesi, M.Ü. Nihad Sayar Yayın ve Yardım Vakfı Yayın No: 414-648, İstanbul.

Cox, G. W. (2012). "The Power of Purse and the Reversionary Budget", http://pscourses.ucsd.edu/ps200b/Cox\%20The\%20power\%20of\%20the\%20pur se\%20and\%20the\%20reversionary\%20budget.pdf, (13.09.2018).

Çağan, N. (2008). "Modern Bütçe Sürecinde Parlamento'nun Rolü”, Bütçe Sürecinde Parlamentonun Değişen Rolü (Uluslararası) Sempozyumu: Bildiri ve Makaleler Kitabı, (Der.) Bütçe Müdürlüğü, TBMM Plan ve Bütçe Komisyonu, Afyonkarahisar, 183-192.

Edizdoğan, N. \& Çetinkaya, Ö. (2014). Kamu Bütçesi, Ekin Yayınevi, Bursa.

Erçin, C. (1937). Hukukî Bakımdan Bütçe, Hapisane Matbaası, Ankara.

Erçin, C. (1938). Bütçe Nazariyat ve Tatbikatı, Devlet Basımevi, İstanbul.

Feyzioğlu, B. N. (1969). Nazari, Tatbiki, Mukayeseli Bütçe; İstanbul Üniversitesi Fen Fakültesi Döner Sermaye Basımevi, İstanbul.

Gürsoy, B. (1981). Kamusal Maliye ikinci Cilt: Bütçe, Ankara Üniversitesi Siyasal Bilgiler Fakültesi Yayın No: 481, Sevinç Matbaası, Ankara.

Mutluer, K.; Öner, E. \& Kesik A. (2005). Bütçe Hukuku, İstanbul Bilgi Üniversitesi Yayınları: 99, İstanbul.

Pelin, F. (1944). Finans IIImi: Bütçe, İstanbul Üniversitesi İktisat Fakültesi Yayın No: 22, Akgün Matbaası, İstanbul.

Selen, U. \& Tarhan, B. (2014). Türkiye'de Bütçe Hakkı Algısı, Uşak Üniversitesi Yayını, Uşak.

TBMM Zabıt Ceridesi (Yirmi Dördüncü İçtima), Devre: II, Cilt:8, İçtima Senesi: II, 30.3.1340 (30.3.1924), https://www.tbmm.gov.tr/tutanaklar/TUTANAK/TBMM/ d02/c008/tbmm02008024.pdf, (19.09.2018).

Tüğen, K. (2018). Devlet Bütçesi, Bassaray Matbaası, İzmir.

Wehner, J. (2006). "Assessing the Power of the Purse: An Index of Legislative Budget Institutions", Political Studies, 54, 767-785.

Yüksel, N. (2007). "Türk Anayasa Yargısında Arındırma(ma) Sorunu: Bütçe Yasası ve Anayasa Yargısı", Yasama Dergisi, 6, 113-156. 


\section{Mevzuat:}

2018/3 Sayılı Üst Kademe Kamu Yöneticileri ile Kamu Kurum ve Kuruluşlarında Atama Usûllerine Dair Cumhurbaşkanlığı Kararnamesi (Kararname Numarası: 3): http://www.resmigazete.gov.tr/eskiler/2018/07/20180710-3.pdf, (16.04.2019).

2018/5 sayılı Cumhurbaşkanlığı Genelgesi: http://www.resmigazete.gov.tr/ eskiler/2018/08/20180809-11.pdf, (15.04.2019).

6761 sayılı Kamu Malî Yönetimi ve Kontrol Kanunu ile Bazı Kanunlarda Değişiklik Yapılması Hakkında Kanunun: http://www.resmigazete.gov.tr/eskiler/2016/ 11/20161124-8.htm, (25.12.2018).

703 sayılı Anayasada Yapılan Değişikliklere Uyum Sağlanması Amacıla Bazı Kanun Ve Kanun Hükmünde Kararnamelerde Değişiklik Yapılması Hakkında Kanun Hükmünde Kararname: http://www.mevzuat.gov.tr/pdff.png, (08.03.2019).

iç Kontrol ve Ön Mali Kontrole ilişkin Usul ve Esaslar (31.12.2005 tarih ve 26040 sayılı RG): http://www.mevzuat.gov.tr/Metin.Aspx?MevzuatKod=7.5.9813\&Mevzuat Iliski=0\&sourceXmISearch=\%C4\%B0\%C3\%A7\%20Kontrol\%20ve\%20\%C3\%96n\%2 OMali\%20Kontrole\%20\%C4\%B0li\%C5\%9Fkin\%20Usul\%20ve\%20Esaslar, (25.08.2018).

Kamu Mali Yönetimi ve Kontrol Kanunu: http://www.mevzuat.gov.tr/Metin1. Aspx?MevzuatKod=1.5.5018\&Mevzuatlliski=0\&sourceXmlSearch=5018\&Tur=1 \&Tertip $=5 \& \mathrm{No}=5018,(25.02 .2019)$.

Muhasebe-i Umumiye Kanunu (mülga): http://www.mevzuat.gov.tr/pdff.png, (26.05.2018).

T.C. Anayasası, http://www.mevzuat.gov.tr/MevzuatMetin/1.5.2709.pdf, (24.07.2019). TBMM İçtüzüğü: https://www.tbmm.gov.tr/docs/ictuzuk.pdf, (27.09.2018).

\section{Anayasa Mahkemesi Kararları:}

E.: 2012/102 K.: 2012/207 sayılı Karar (2/04/2013 tarih ve 28606 sayılı RG): http://www.resmigazete.gov.tr/eskiler/2013/04/20130402M1-4.htm, (05.08.2019).

E.:2011/21 K.:2013/36 sayılı Karar (6.03.2014 tarih ve 28933 sayılı RG): http://www.resmigazete.gov.tr/eskiler/2014/03/20140306-12.htm, (05/08/2019). 